\title{
The Effect of Distress Tolerance Skills Training on Emotional Regulation and Improvement of Alexithymia in Patients with Masturbation
}

\author{
Zahra Taheri ${ }^{1}$, Hasan Rezaee Jamaoei ${ }^{* 2}$, Saeed Zamani ${ }^{3}$ \\ 1. M.A. In psychology, Department of Psychology, Sciences and Research Unit, Islamic Azad University, Tehran, Iran \\ 2. Assistant Professor, Department of Psychology, Najafabad Branch, Islamic Azad University, Najafabad, Iran \\ 3. M.A. in Clinical Psychology, Department of Psychology, Hamedan Branch, Islamic Azad University, Hamedan, Iran \\ Accepted: October 13, 2018
}

\begin{abstract}
Background and Purpose: Masturbation is a complement to sexual desire that does not require a sexual partner and increases suddenly due to hormonal changes in adolescence. The purpose of this study was to investigate the effect of distress tolerance training on alexithymia, emotional regulation, and distress tolerance in 11-14 year-old subjects with masturbation.

Method: In a case study of multiple baseline type, the 8-hour treatment process was performed on four subjects. Four outpatient with masturbation were evaluated by Toronto alexithymia scale (TAS-20) (Toronto, 2005), cognitive emotion regulation questionnaire (Garnowski et al., 2001) and tolerance of emotional distress (Alawi, 2011) before, during, and after the therapy. The percent recovery was used to measure the recovery rate.

Results: Results showed that distress tolerance training was effective in improving alexithymia and increasing emotional regulation and tolerance of distress. The rate of recovery was $44.48 \%$ for alexithymia, $29.50 \%$ for emotional regulation, and $39.38 \%$ for emotional distress.

Conclusion: Based on the results of this study, it can be concluded that distress tolerance training makes it possible for subjects with masturbation to identify their positive and negative emotions and thus decreases their emotional deficiency and increases their ability of emotional regulation and their level of stress tolerance.
\end{abstract}

Keywords: Distress tolerance training, emotional deficit, emotional regulation, masturbation

Citation: Taheri Z, Rezaee Jamaoei H, Zamani S. The effect of distress tolerance education on emotional regulation and improvement of alexithymia in patients with masturbation. Quarterly Journal of Child Mental Health. 2019; 6(1): 54-69.

*Corresponding author: Hasan Rezaee Jamaoei, Assistant Professor, Department of Psychology, Najafabad Branch, Islamic Azad University, Najafabad, Iran. 


\title{
تأثير آموزش تحمل بريشانى بر توانايى تنظيم هيجانى و بهبود نارسايى هيجانى مبتلايان به اختلال نيمهبالينى خودارضايى
}

\author{
زهرا طاهرى'، حسن رضايى جمالوئى "r، سعيد زمانى

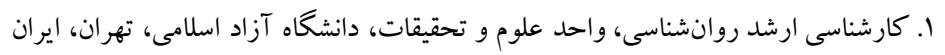

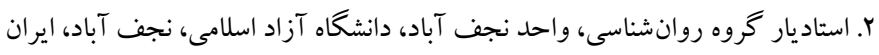

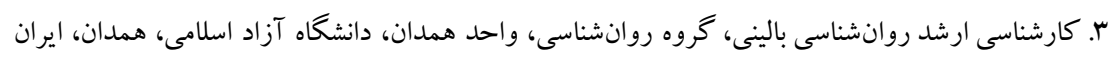

تاريخ بذيرش:

تاريخ دريافت: 9V/PY

\section{جكt:}

زمينه و هدف: خودارضـايى مكمل تمايل جنسى اسـت كه نيازى به وجود شريكك جنسى نيست و به دليل تغييرات هورمورنى دوران

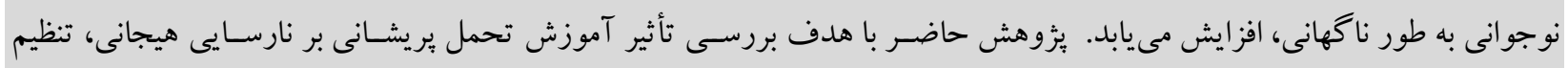

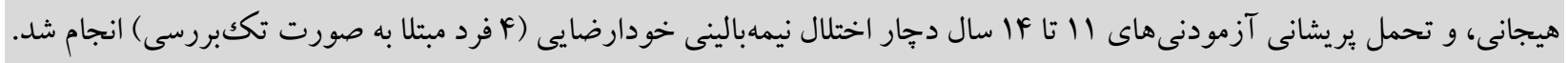

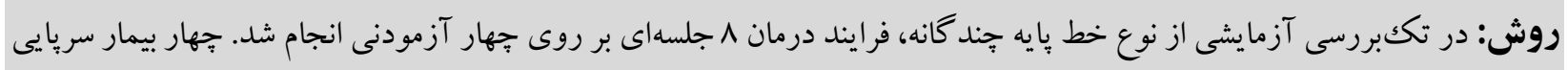

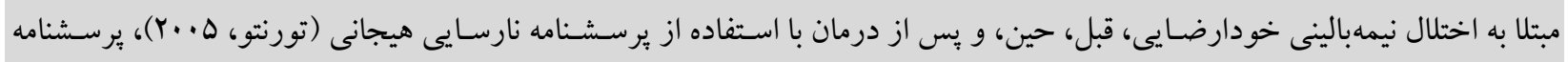

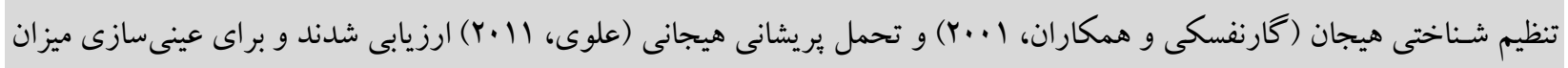
بهبودى از فرمول درصدى بهبودى استفاده شد.

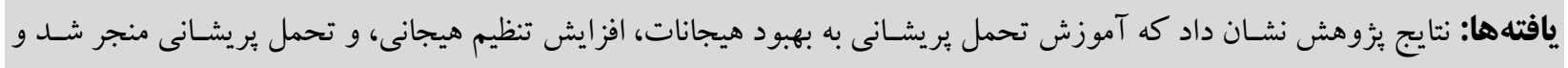

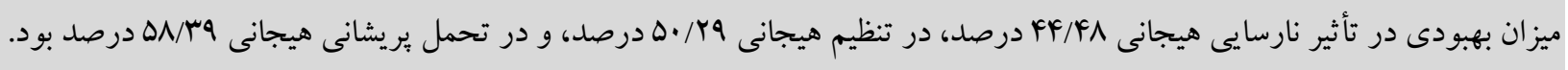

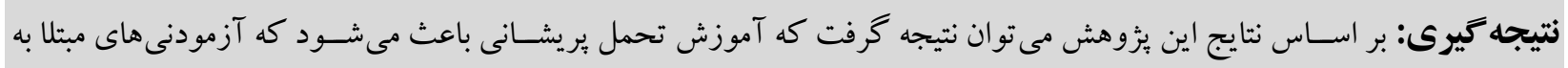

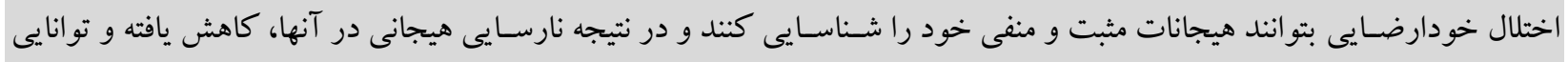
تنظيم هيجان و سطح تحمل تنيدگى، افزايش مى يابد. كليدوازهها: آموزش تحمل بريشانى، نارسايى هيجانى، تنظيم هيجانى، خودارضايى

* نويسنده مسئول: حسن رضايى جمالوئى، استاديار كروه روانشناسى، واحد نجف آباد، دانشكاه آزاد اسلامى، نجف آباد، ايران. تلفن:

ايميل:Hassanrezaeejamaloe@iaun.ac.ir 
نوجوانان اسـتـ. منع هاى اشــتباه و شـــديد، تهديدها و يرهيز مقدمه دادنهاى مكرر از يكك فعاليت، سـبب مى شــود كودك به به آن

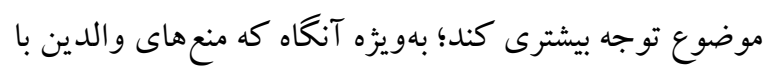

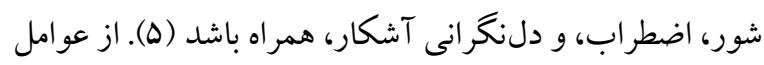

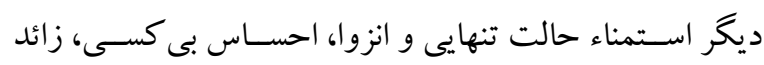

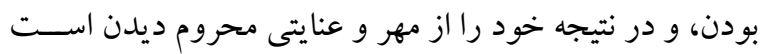
كه موجبات لغزش و انحر اف را براى كودكك و نوجوان فراهم

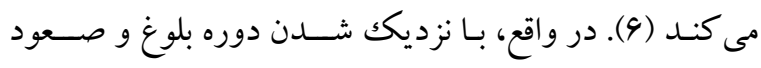

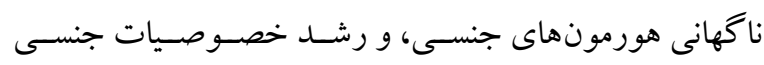

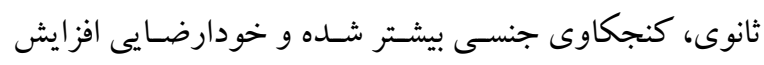

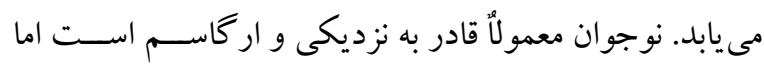

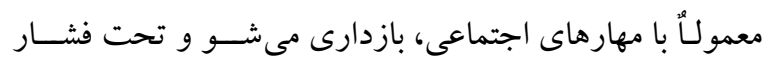

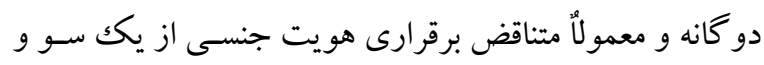
مهار تكانه هاى جنسى خود از سوى ديخر، قرار دارد. نتيجه آن

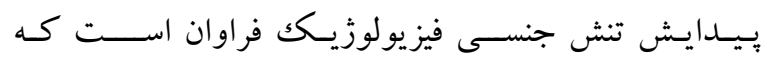

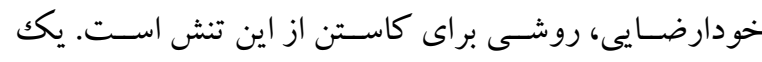

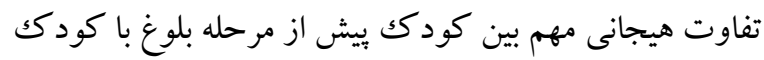

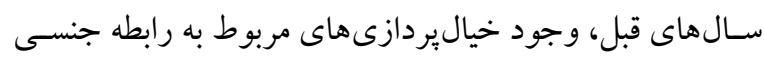

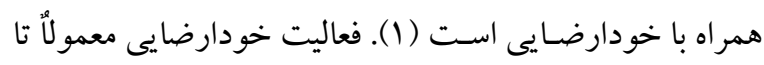
جوانى دوام يافته و بالاخره جاى خود را به رابطه جنسى طبيعى مىدهد. البته بسـيارى از جوانان بدلايل مختلفى مانند تأخير در

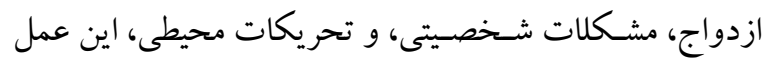

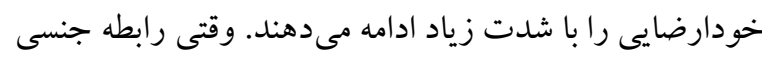
رضسايت بخش نيسـت يا به علت بيمارى يا فقدان يار جنسىى

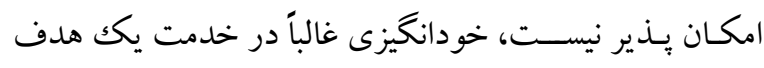
انطباقى، با تر كيب لذت حسى و رفع تنش به كار كرفته مى شود

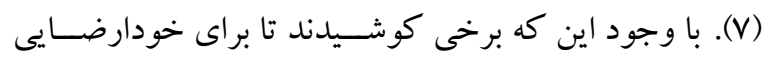

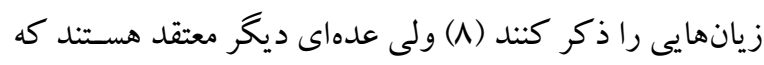

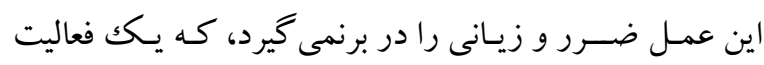

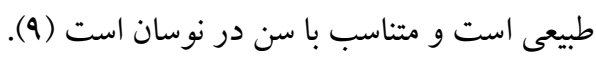
غريزه جنسى در وجود انسـان غريزهاى بسيار نيرومند و ارزنده است كه در صورت قرار گرفتن در مسير شرعى و صحيح خود

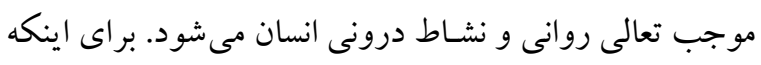
اين غريزه ارضـاء شـود انجام رفتار جنسى همواره براى بيشـتر

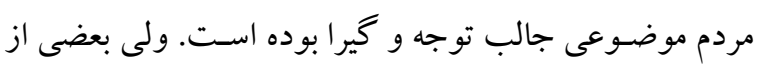

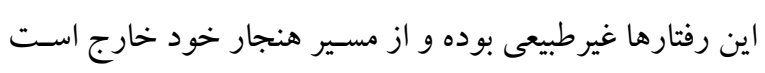

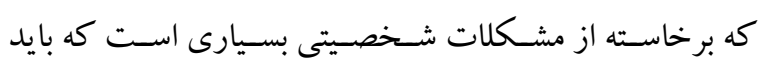

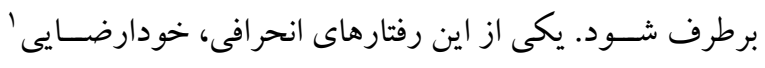

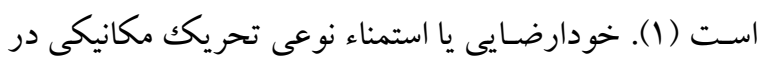

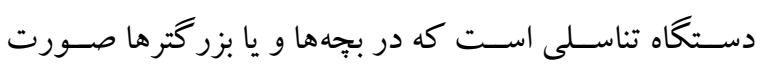
مى گيرد. فرد عملـاً بـا خود كـارى مى كنــ كه به تخليه هيجان

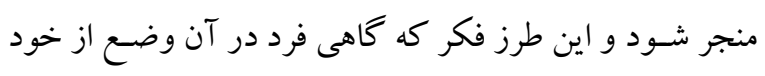

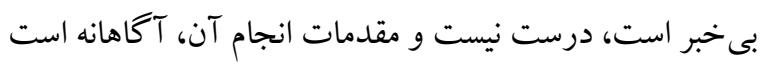

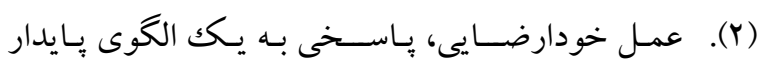

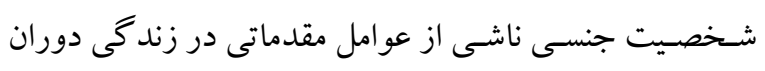

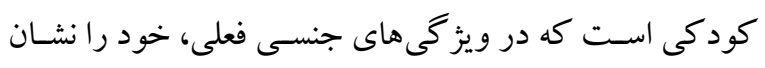

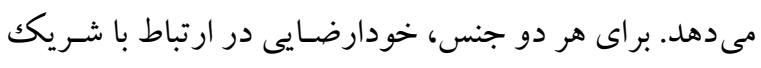

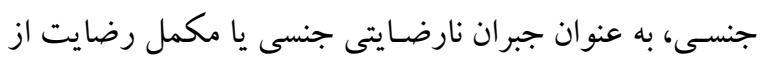

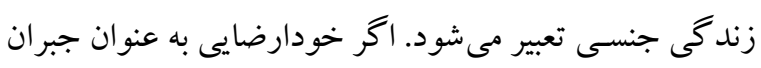
نارضايتى جنسى ديده شود، مىتوان انتظار داشت كه بيشتر در

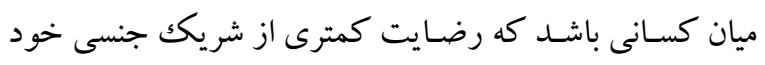
دارند (r). اخر خودارضايى به عنوان مكمل تمايل جنسى ديده شـود، در اين صورت، ارتباطى به وجود شريك جنسى ندارد.

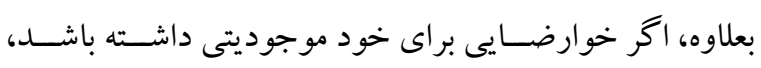
مى توان انتظار داشـت كه بيشتر در ميان افر ادى باشد كه تمايل

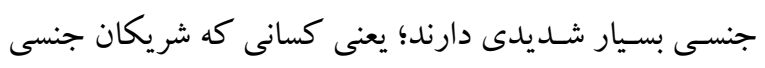

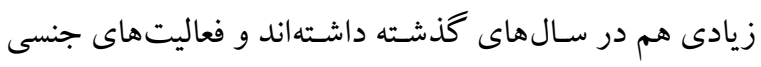
زيادى با شريكك جنسى ثابت خود داشتهاند (F).

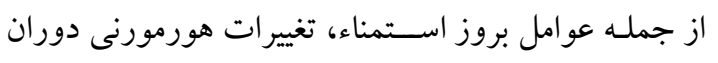

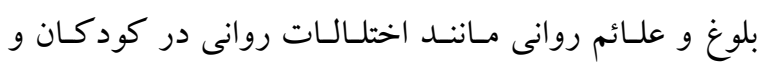


كنند، و در زمينه هيجانهاى خاص، جِگونه با ديخران رفتار

كنند (1) ).

در حقيقت تنظيم هيجان به معناى تلاش افراد براى تأثير

كذاشـتن روى نوع، زمان و جخگونكى تجربه و بيان، تغيير

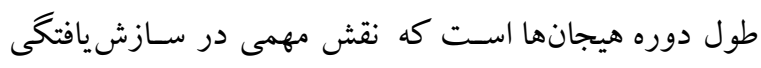

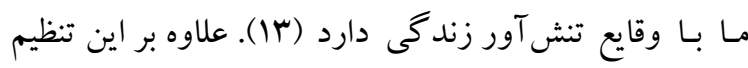
هيجان نقش برجستهاى در ايجاد و گسترش اختلالات هيجانى

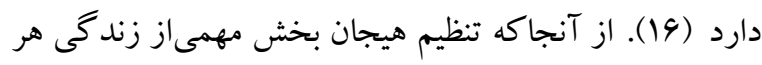

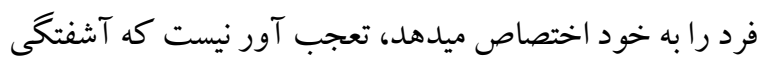
در هيجـان و تنظيم آن مى تواند منجر به آســيب روانى شـــود

تحمل هيجان شـامل ايجاد افكار و رفتارهايى اسـت كه به

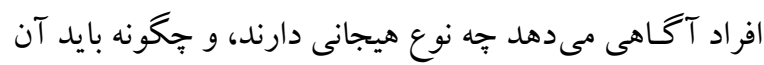

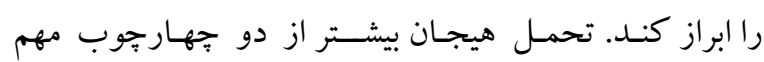
بررسى مىشوند كه عبارتند از: راهبردهاى تنظيم هيجان كه هـ

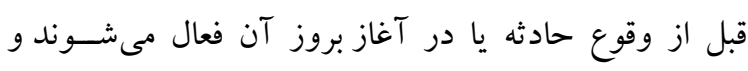

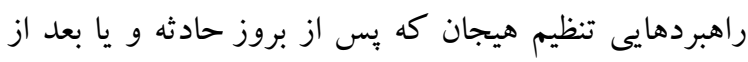

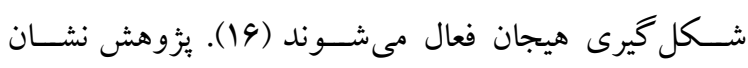

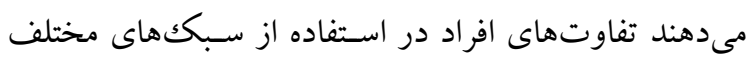

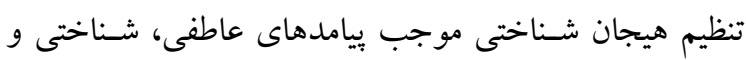
اجتماعى مختلفى مى شود (IV).

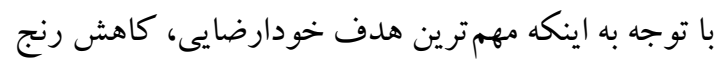

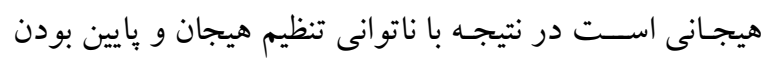

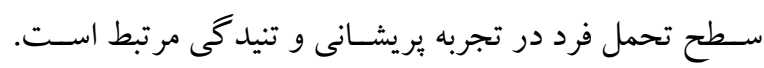

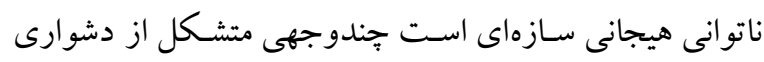

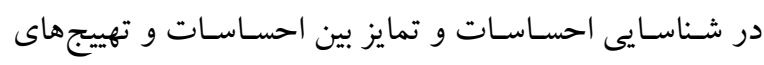

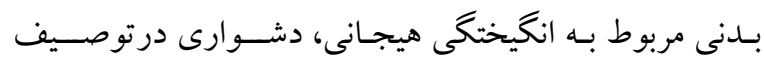

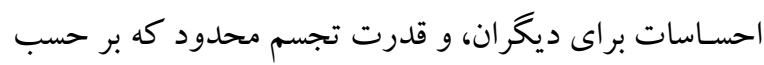

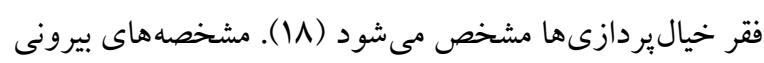

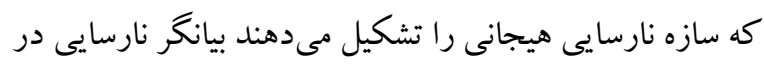

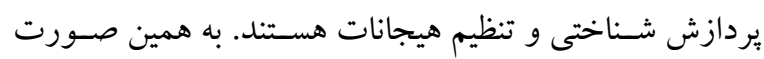

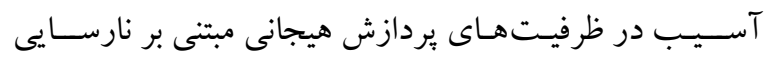

حـالات وقوع اسـتمنـاء در دختران، همان مشــخصـات و

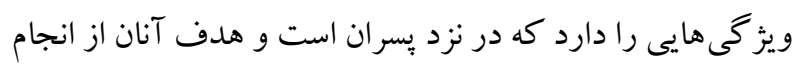

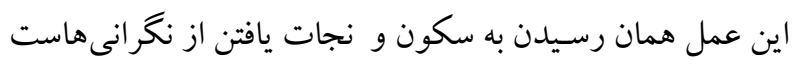

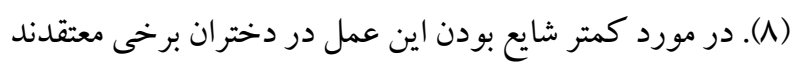
جون دستخاه تناسلى جنس ماده در درون بدن قرار دارد و كمتر

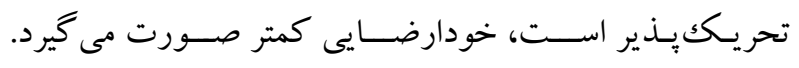

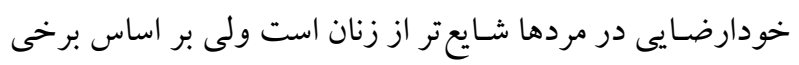

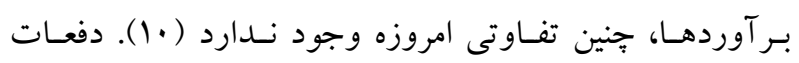

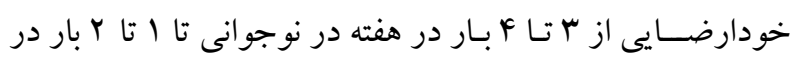
هفته در بزر گسالى، فرق مى كند. هر دو جنس كودكى در حدود الز

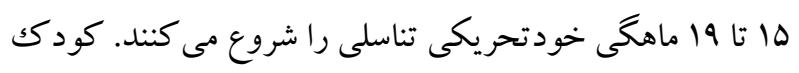

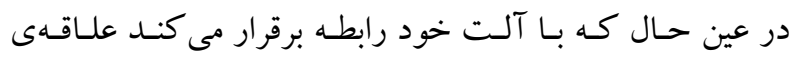
فزايندهاى به آلت تناسـلى ديخر ان- والدين، كود كان، و همجِنين

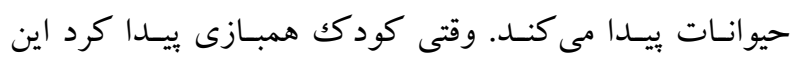

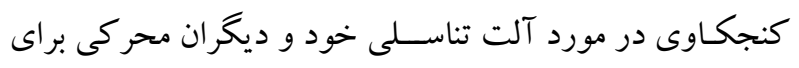

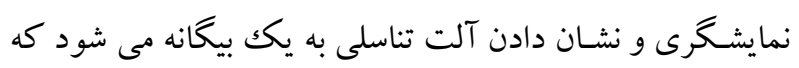

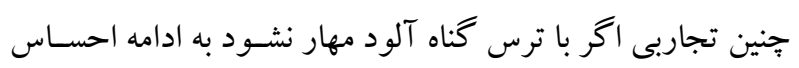

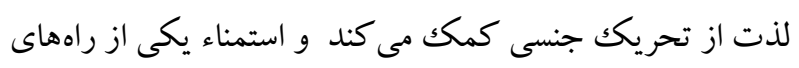

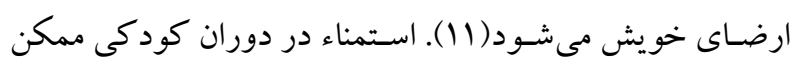

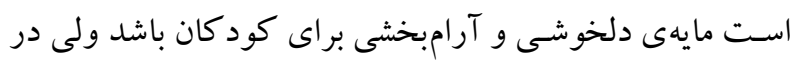

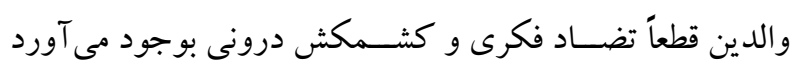

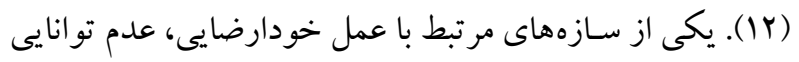

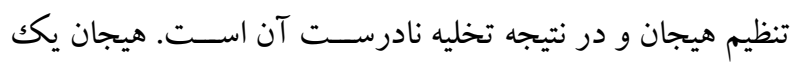

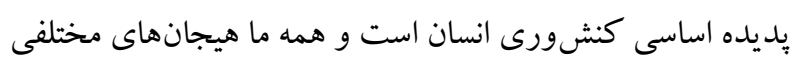

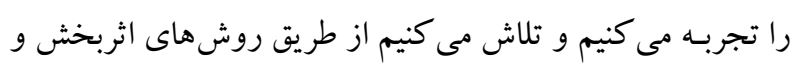

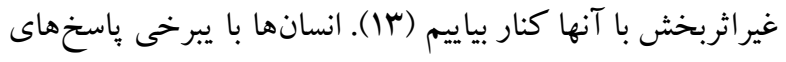

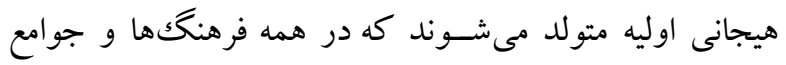
مشابه است ولى هيج كاه دو فرد پياسخهاى هيجانى يكسانى به

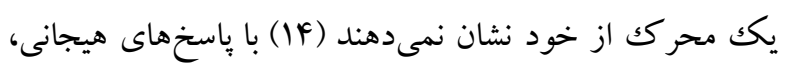

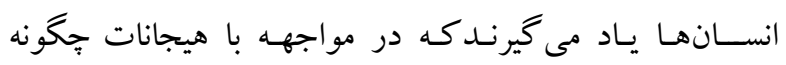
رفتاركنند، جِگونه تجارب هيجانى را به صـورت كلامى بيان 
بريشانى مبتلايان به اختلال خودارضايى شديد در دامنه سنى 11

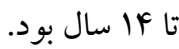

روش

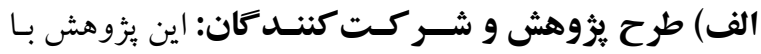

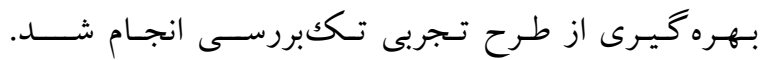

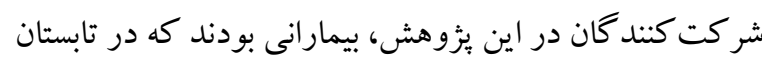

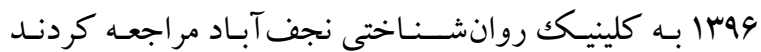

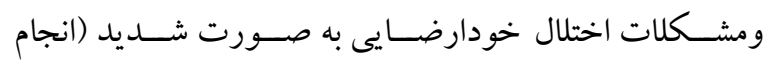
خودارضـايى به صورت ب تا F بار در روز) داشتند. نمونه مورد

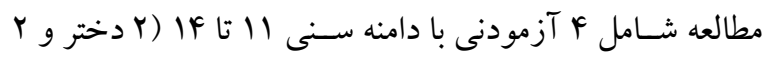

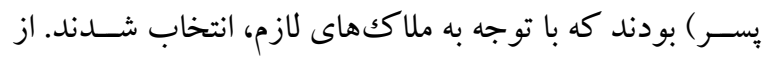

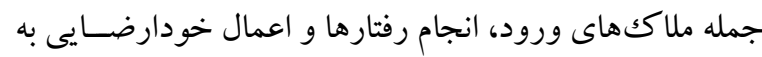
صـورت ب تأ أ بار در روز، نداشـتن اختلال شـخصـيت، اختلال رفتـار هنجـارى، اختلـال نـافرمانى مقابلهاى، و عدم تشـخيص اختلالات جنسى بود. همجنين اين افراد مشـكلات جسـمى كه

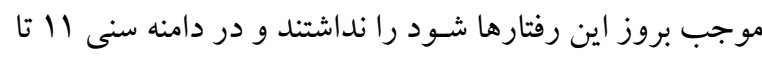

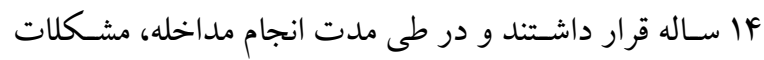

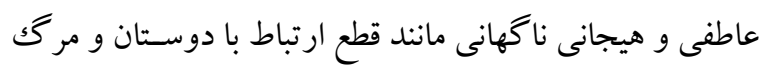
اعضاى خانو اده وجود نداشته است. مراجع اول، دختر باســالـه، كلـاس هفتم، و فرزنــد دوم

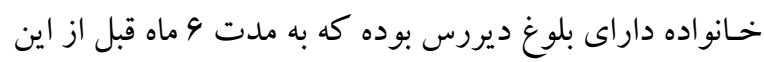

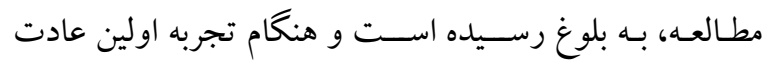

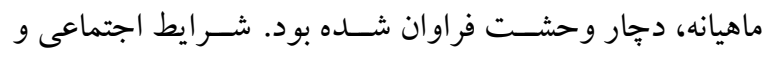
اقتصـادى خانواده اين مراجع بسـيار پايين و در كودكى دجار

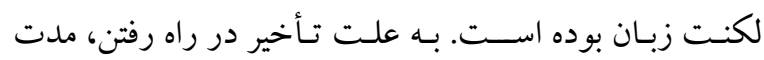

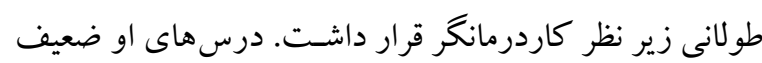

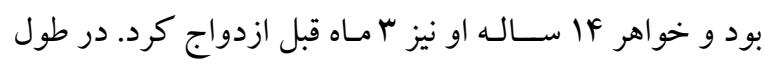

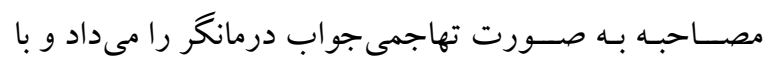
عصبانيت نتايج مصاحبه و سوالات را به نفع خود تغيير مىداد و همواره نقش ظالم و مظلوم را بازى مى كرد.
هيجـانى ممكن اسـت يكك عـامـل خطر احتمـالى براى انواع مشكلات سلامت روان باشند (9 1). ئزوهش هاى مختلفى درباره آموزش تحمل بريشانى صورت گرفته است. لينهان و همكاران

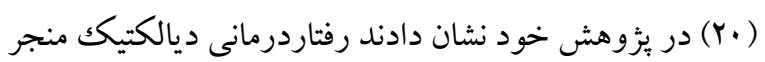
به كاهش رفتارهاى تكانهاى در افر اد مبتلا به اختلال شـخصيت

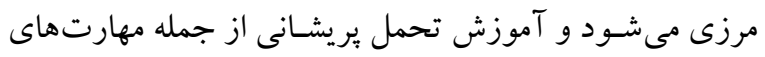

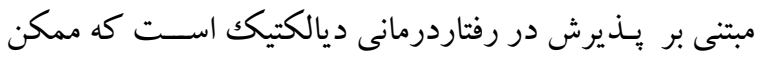

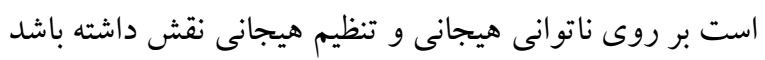

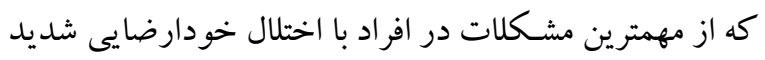
است. جويى و همكاران (YI)، رابطه بين خودارضايى با تحمل بريشـانى وبايين را بررسـى كرد و نتايج نشــان داد بين تنظيم هيجانى، تحمل بريشانى، و خودارضايى ارتباط مستقيمى وجود برد

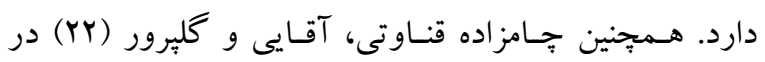

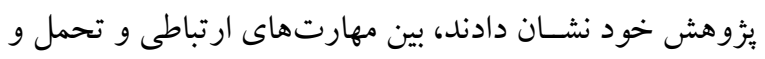
تنظيم هيجانى، ارتباط مستقيمى وجود دارد.

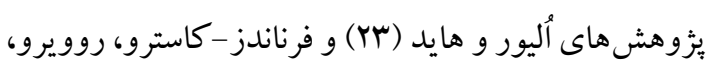

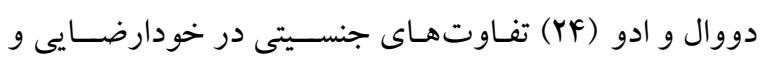

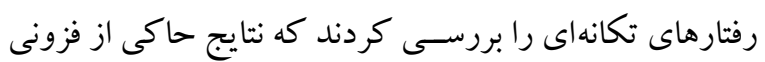
ميز ان شـيوع رفتارهاى خودارضــايى در يســــان بوده اســت. بوهوس و همكارن (YD) مهارت هاى مبتنى بر يذيرش و و تغيير در رفتاردرمانى ديالكتيك را بر رفتارهاى مخاطره آميز بيماران

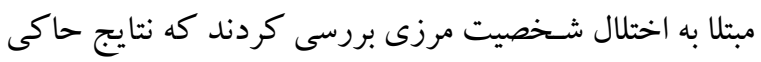

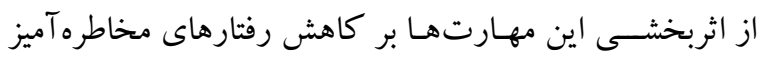
بوده است. در اين ارتباط كلدستون و كلدستون (Y) إن، يوشانها،

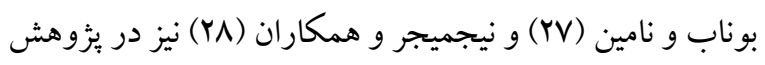

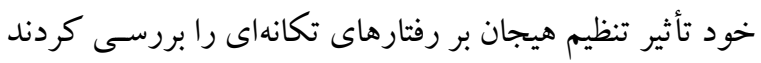

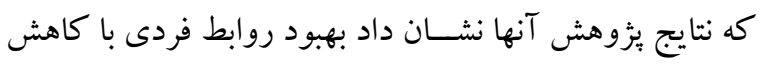
بـــنظيمى هيجـان، ارتبـاط مسـتقيمى دارد. بـا توجه به نتايج

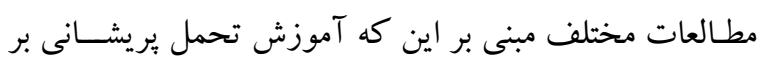

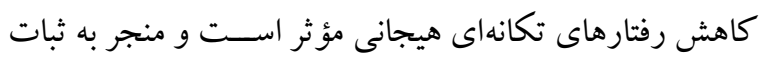

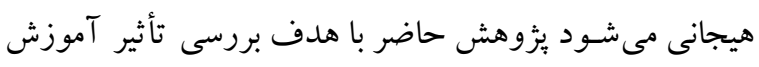

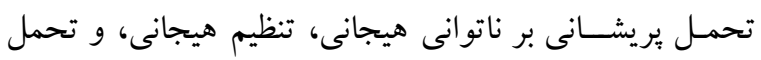


برسـشــنامه •r ســوال دارد كه با مقياس ليكرت سـه درجهاى

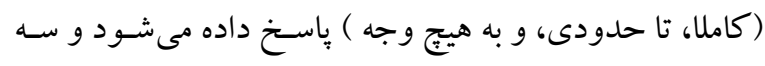

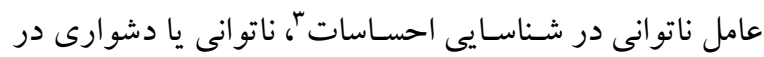
توصيف احساسات"، و سبك تفكر عينى ه را مورد ارزيابى قرار مىدهـد. روايى همزمـان مقياس نارســايى هيجانى بر حســب

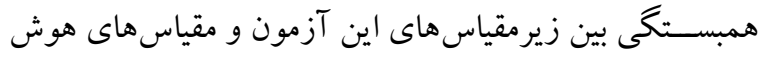

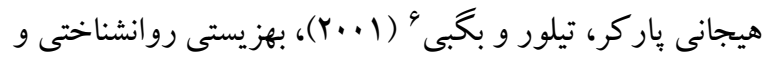

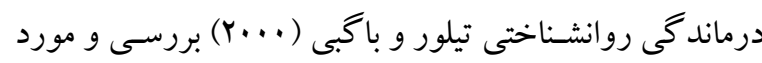

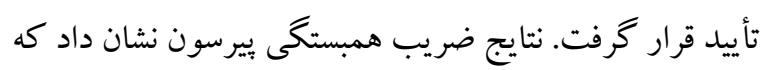
بين نمره آزمودنى ها در مقياس نارسـايى هيجانى كل با هوش

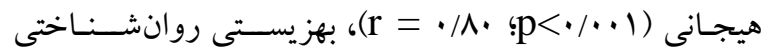

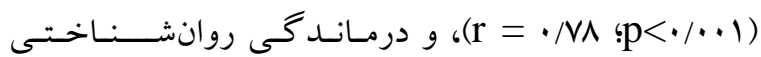

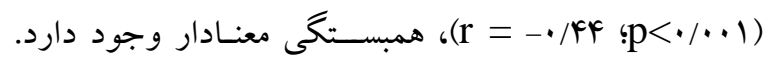

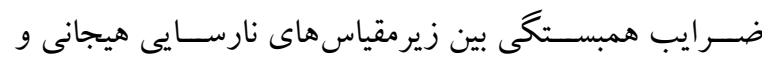
متغيرهاى فوق نيز معنادار بود (Y9). ابو القاسـمى، رضسـي و و

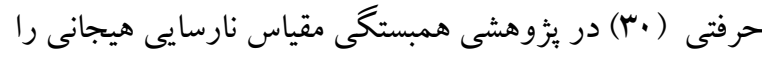

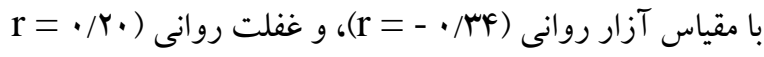

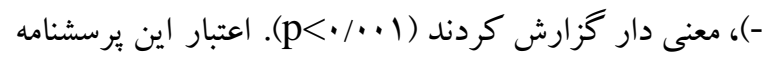
در مطالعه حاضر نيز با استفاده از ضريب آلفاى كرونباخ، rه/ • بهدست آمده است. r. تنظيم هيجانى: برسـشــنامه تنظيم شــناختى هيجان توسـط

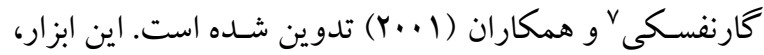

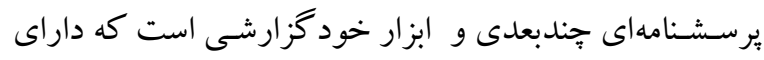

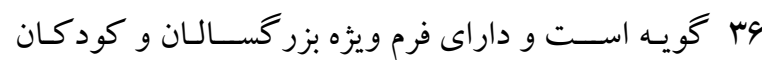

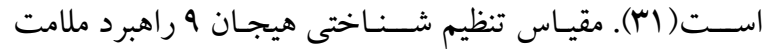
خويش، يـذيرش، نشــخوار گرى، تمركز مجدد مثبت، تمركز

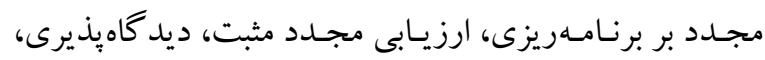

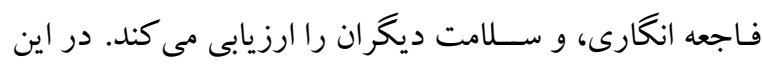
يرسشنامه از فرد خو استه مى شود تا واكنش خود راد در مواجه با ليا

5. Externally oriented thinking

6. Parker, Taylor, Bagby

7. Garnefski Cognitive Emotion Regulation Questionnaire
مراجع دوم، دختر سا سـاله كلاس هشـتم بود كه ينج سـال قبل به بلوغ زودرس رسيد و منزوى و تنها است. او دختر ينجم در خانواده 1 نفره اسـت كه اضطراب شديد دارد، بهطورى كه در Y ســال كذشـــه طبق نظر مشــاور برورشــى مدرســهـ به روانشــناس ارجاع داده شــده بود. ســابقه صــرع و بيمارى

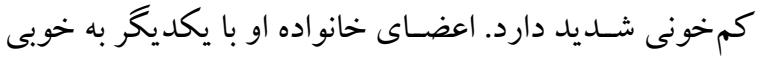
برخورد نمى كنند و در تلاش براى اثبات حرف خود هسـتند و از مكانيزم دفاعى همه يا هيج، فراوان استفاده مى كنند.

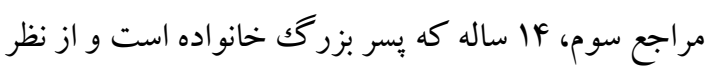
شـر ايط اجتماعى و اقتصـادى در سـطح بالايى هسـتند ولى بدر خانواده مدتى است خانو اده را تركى كرده و مادر دجار اختلال افسردگگى شـديد است و دارو مصرف مى كند. طبق كفتههاى مراجع، يكى از بستگان از خانه بدون سكنه اين خانو اده استفاده كرده و افر ادى راصيغه كرده و به خانه آورده بود و هنگامى كه اين مراجع با صسحنه حضور اين افراد در خانه مواجهه شد او را نيز درگير مسـائل جنسى خود كردند و تا به حال كسى اطللاعى درباره اين موضوع ندارد. اين فرد مدت جند ماه مصرف شيشه داشــتـهـ كه در بيمارســتان روان ترك كرد و اكنون مشــكل خودارضايى شديد دارد. مراجع جهارم، يسر الهـالهاى اسـت كه در كلاس شـشم تحصــيل مى كند. او فرزند اول خانواده اســت كه دجار بلوغ زودرس بوده است. اين مراجع اختلال خودارضايى شديد دارد و هم اكنون اختلال روانشــناختى ديخرى در او تشــخيص داده نشد. ب) ابزار: در اين يثوهش از ابزارهاى زير استفاده شده است. ا. نارســايى هيجانى: يرســـــنامه نارسـايى هيجانى تورنتو' مخصـوص كود كان و نوجوانان از نسـخه اصـلى برسـشــنامه نارســايى هيجانى بزر كســالان خرفته شــده و توســط ريف ، اسـتروالد و نزو گت ب در سـال ه ...r سـاخته شـده اسـت. اين

1. Toronto Alexithymia Scale-20 (FTAS-20)

2. Reef, Stroud, Nzogt

3. Difficulty identifying feelings

4. Difficulty describing feelings 
و و بايايى متوسطى را براى خردهمقياسها گز ارش (a= · ·NI)

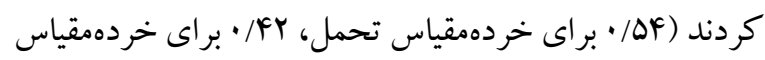

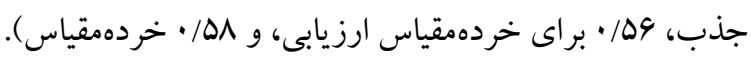

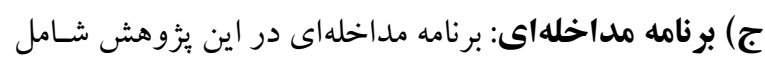

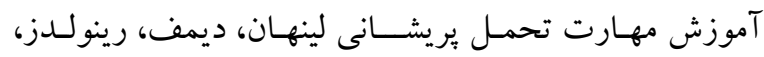

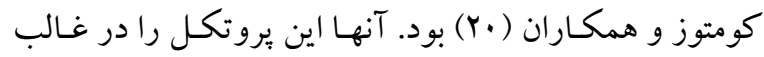

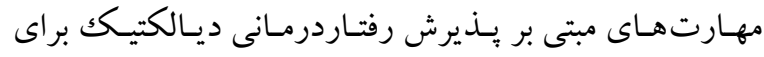

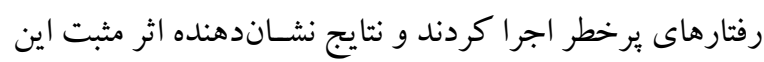

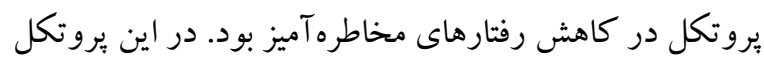

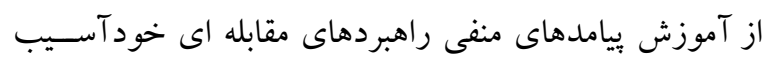
رسان، مهارت خود آرامشى، شناسايى قدرت برتر و ارتباط بهتر با قدرت برتر، بذيرش بنيادين و اسـتفاده از بذيرش بنادين، و و

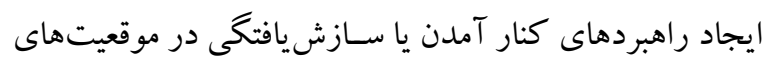

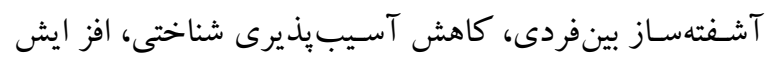

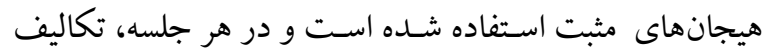

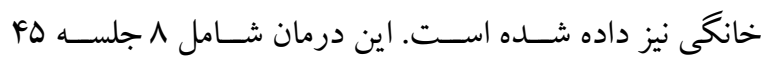

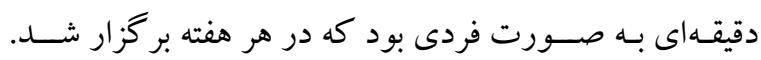
محتواى هر ^ملسه مداخله در جدول ا ارائه شده است.
تجـارب تهـديــآميز و رويـدادهـاى تنش آور زنـدگى كـه بـهـ تاز گى تجربه كردهاند، مشـخص كند. اين برسشنامه داراى فرم

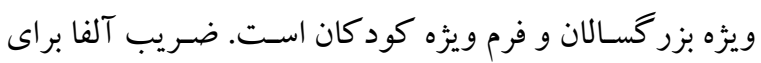

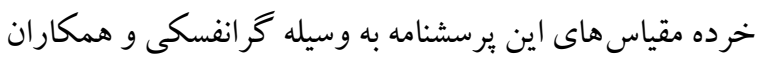

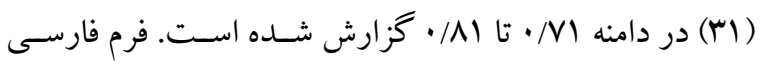
اين مقياس به وسـيله سـامانى و صادقى (rr) مورد اعتباريابى و تأييد قرار كرفته است.

r. تحمل بريشـانى: اين ابزار يكك شاخص خودسنجى تحمل

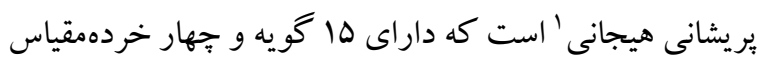
اسـت. خردهمقياس ها شامل تحمل (تحمل بريشـانى هيجانى)، جـذب (جذب شدن توسط هيجانات منفى)، ارزيابى (بر آورد ذهنى بريشانى)، و تنظيم (تنظيم تلاشها براى تسكين يريشانى)

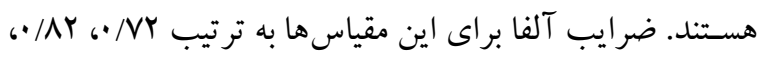

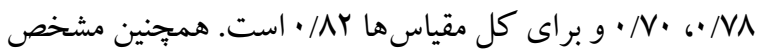

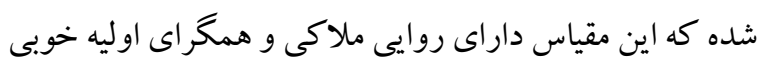

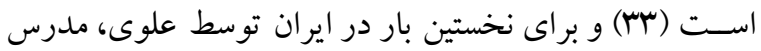
غروى، امينى يزدى، و صالحى فدروى (MF) مورد استفاده قرار

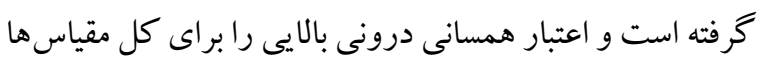

\section{جدول ا: محتواى جلسات برنامه آموزش مهارت تحمل يريشانى لينهان و همكاران (·r)}

\begin{tabular}{|c|c|c|c|}
\hline كليف منزل & كليف جارى & آموزش مهارت & 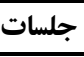 \\
\hline تمرين توجه بركردانى از طريق فعاليتهاى لذت بخش & تكليف مهارت هاى يرت & آموزش بيامدهاى منفى راهبردهاى كنار آمدن خود & \\
\hline خودارضايى و تهيه فهر ست فعاليتهاى لذت بخش & كردن حواس از رفتارهاى & آسيبرسان، تمر ين يذيرش بنيادين، تمرين توجه بركردانى از & 1 \\
\hline ديخر و كنجاندن آن در برنامه هفتخى & 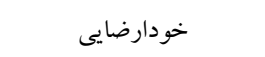 & رفتارهاى خو دارضايى & \\
\hline توجه بر گردانى از طريق شمارش، تدوين برنامه توجه & تكاليف و كارهاى روزمرهره & 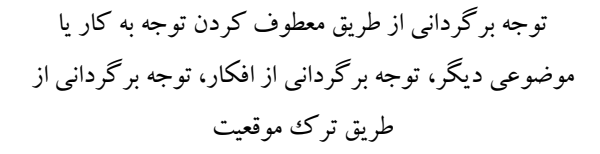 & r \\
\hline تدوين طرح هاى آرميد گى شناختى در منزل و در & 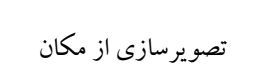 & مهارت خود آرامشبخشى، خود آرامش بخشى با استفاده از & \\
\hline خارج از منزل & امن (تجسم محل امن) & 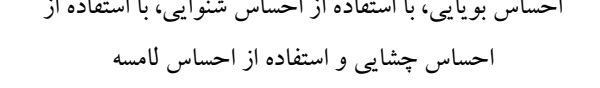 & $r$ \\
\hline تمرين عمل متعهدانه & تمرين زند آرامى ارزيجد شدهد با & تن آرامى ، آرامش وابسته به نشانه، كشف مجدد ارزشها، كشف & F \\
\hline تمرين فعاليتهاى قدرت برتر & زنمرين ذهر زمان حال، & 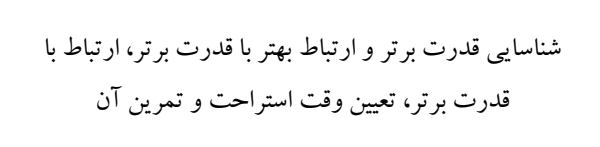 & $\Delta$ \\
\hline
\end{tabular}




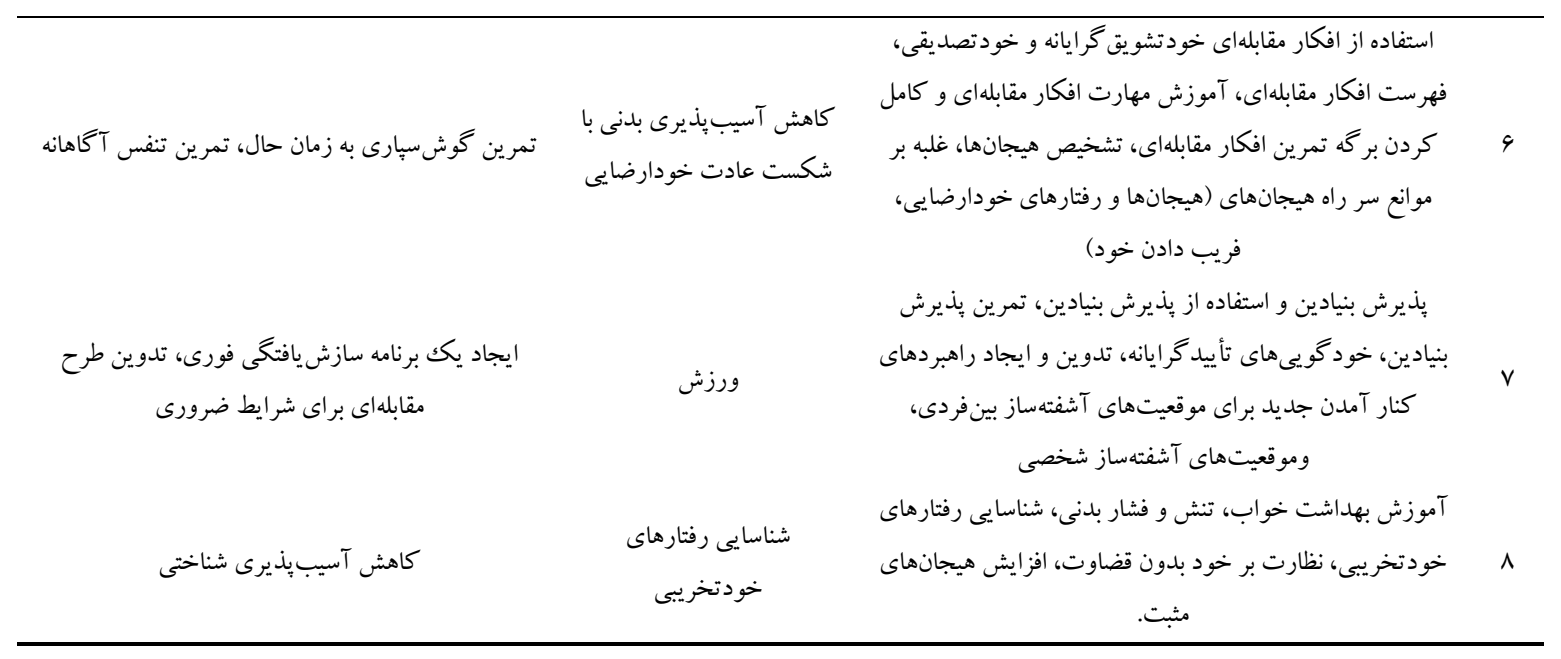

. . . . ســاعت كذرانده بود. جهت اجراى برنامه هاى مداخلهاى،

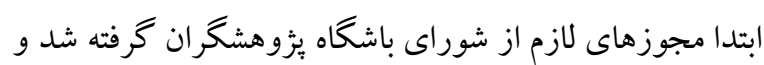

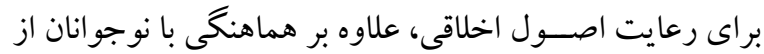

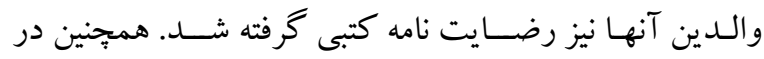
خصوص محر مانه ماندن اطلاعات مراجع و محتواى خصوصى

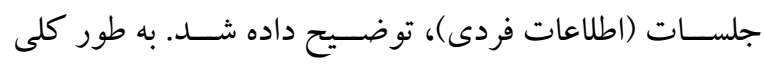
ملاحظات اخلاقى كه در اين مطالعه رعايت شد بدين شرح بود: () احترام به اصـل رازدارى، r) ارايه اطلاعات كافى در مورد

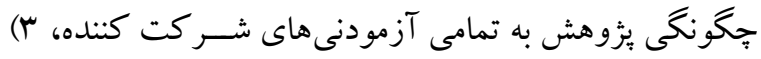

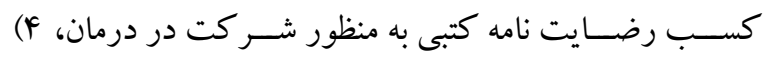

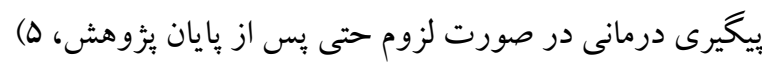

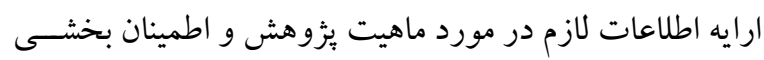
بابت محرمانه بودن اطلاعات، 9) امكان انصر اف آزمودنىها در

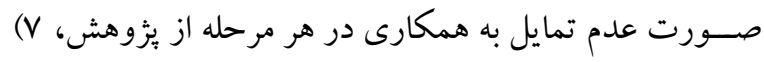

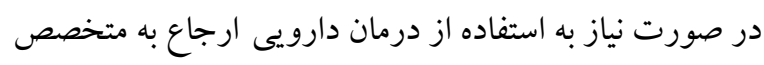
مربوطه حين و يس از اتمام جلسات مداخله.

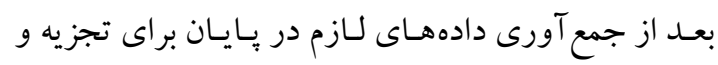

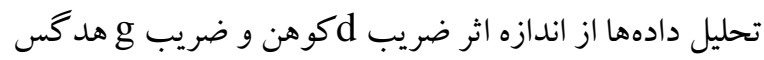
|ستفاده شد.
د) روش اجرا: هر يكك از \& مراجع در جلسـات انفرادى در كلينيك روانشـناختى شـركت كردند. جلسات مداخله در هر

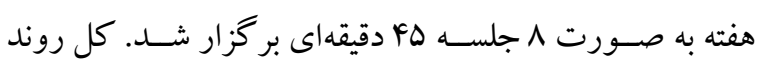

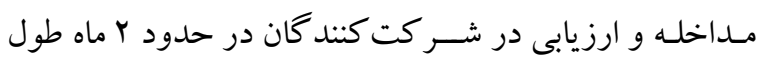
كشيد. كل جلسات مداخله به صورت فردى انجام شد. ابتدا از هر جهار مراجع برسـشـنامه نارسـايى هيجانى، تنظيم شــناختى

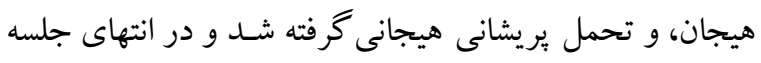

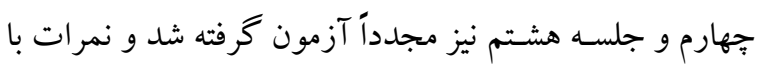

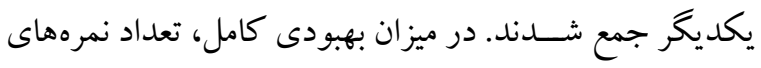
كاهش يافته را با يكديخر جمع مى كنيم كه بدين ترتيب هر سه

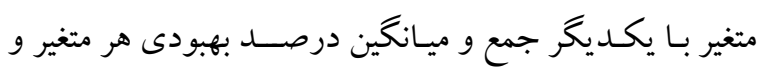
متغير كلى كرفته شد. در ابتداى هر جلسـه توضيحاتى درباره محتواى جلسه داده مىشـــــ و ســـس آموزش لازم ارائه شـــده و از مراجع درباره

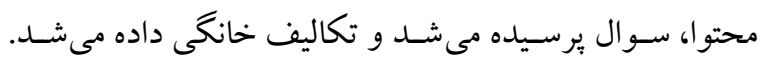
علاوه بر تكاليف خانكىى، تكليف جارى نيز داده مىشد، به اين

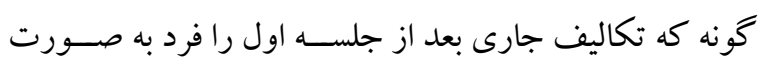

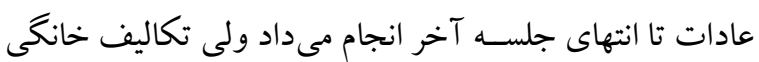

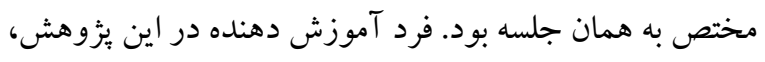
داراى دكتراى تخصصى روانشناسى سلامت بوده و دورههاى

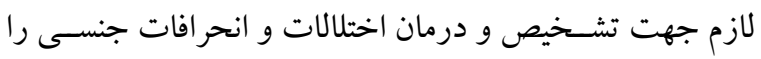

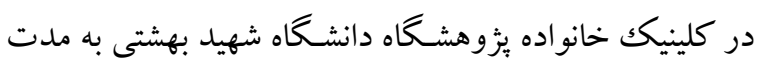


احساسات، ناتوانى در توصيف احساسات، و سبك تفكر عينى

يافتهها

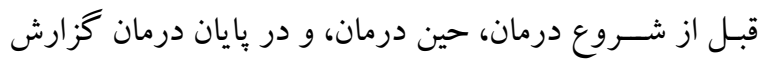

در جدول Y شـاخصهاى توصسيفى نمرات نارسـايى هيجانى و

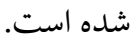

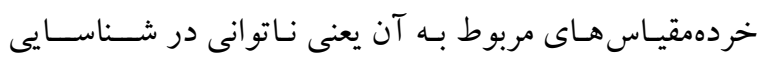

جدول r: شاخصهاى توصيفى نمرات نارسايى هيجانى و خردهمقياسهاى ناتوانى در شناسايى احساسات، ناتوانى در توصيف احساسات، و سبك تفكر عينى قبل از شروع درمان، حين درمان، و در بإيان درمان إنان

\begin{tabular}{|c|c|c|c|c|c|c|c|c|c|}
\hline $\mathbf{p}$ & ضايِرويب & بيشترين & كمترين & كشيدكى & كجى & انحراف & ميانكين & وضعيت & متغير \\
\hline.$/ I V$ & $\cdot / \mathrm{A} \mid$ & $4 q$ & $r$. & 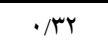 & $\cdot / \wedge \Delta$ & $9 / 1$. & $49 / \pi V$ & يُش آزمون & ناتوانى در \\
\hline.$/ .1$ & . 119 & \&1 & $r$. & .101 &.$/ 9 r$ & $9 / 49$ & $\mathrm{rq} / 91$ & حين آزمون & شناسايى \\
\hline .1 .0 & •/Ar & ro & 10 & 1 & $1 / \cdot r$ & $\Delta / V I$ & $r r / 90$ & يֶ آزمون & احساسات \\
\hline$\cdot / 90$ &.$/ 91$ & \&q & rA & $\cdot / 49$ & .194 & $9 / 9$ & Fr/DQ & ييش آزمون & ناتوانى در \\
\hline$\cdot / \cdot 1$ & $\cdot / A V$ & ro & r & . & $\cdot / A \vee$ & $\Delta / M$ & $M q / q V$ & حين آزمون & توصيف \\
\hline$\cdot / F \Delta$ & •/19 & rq & $r$. &.$/ \cdot 1$ & $1 / \cdot$ & $8 / 19$ & $r q / 90$ & پِ آزمون & احساسات \\
\hline .190 & $\cdot 119$ & Fo & r. & $\cdot / 09$ & $\cdot / \Delta r$ & $9 / 0$. & Fr/TG & يش آزمون & \\
\hline r & $\cdot|A|$ & Fr & rq & 1/ז & ./Ar & 91.0 & rq/9r & حين آزمون & سبك تفكر \\
\hline$\cdot / F V$ &.$/ 9$ & rq & rF & . &.$/ 9 F$ & $\Delta / F F$ & $r 9 / 90$ & پِ آزمون & عينى \\
\hline$\cdot / \mathrm{V} \Delta$ & . & $\Delta r$ & f. & $1 / Y F$ & $\cdot / \Delta F$ & $9 / 94$ & $F F / . q$ & بيش آزمون & \\
\hline 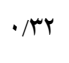 & $\cdot|A|$ & rV & rr &.$/ .1$ & $1 / \cdot r$ & $91 \cdot 1$ & rq/99 & حين آزمون & نمره كا \\
\hline$\cdot / 19$ & $\cdot / 19$ & rr & ru & 1 & $1 / \cdot 1$ & $\Delta / F \Delta$ & ra/vo & يس آزمون & \\
\hline
\end{tabular}

ناتوانى در توصسيف احسـاسـات، و سـبكك تفكر عينى جهت

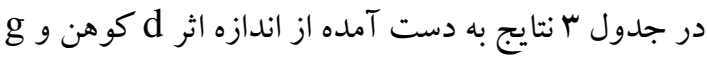
سنجش تفاوت آن و بعد از آموزش گزارش شده است. هد گس گز ارش شـده اسـت. همجنين مقايسه نمرات نارسايى هيجانى و خردهمقياسهاى ناتوانى در شــاسـايى احسـاسـات،

جدول r: مقايسه نمرات نارسايی هيجانى و خردهمقياسهاى ناتوانى در شناسايى احساسات، ناتوانى در توصيف احساسات، و سبك تفكر عينى جهت

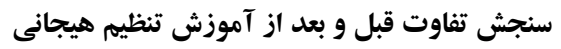

\begin{tabular}{|c|c|c|c|c|c|}
\hline درصد تغييرات & تفسير اندازه اثر & ضريب dكوهن & ضريب g هدكس & تفاوت ميانگين & \\
\hline$\cdot / 49$ & قوى & $1 / 9 F \Delta$ & $1 / \pi \wedge \Delta$ & $r \Delta / V G$ & ناتوانى در شناسايى \\
\hline 每 & متوسط & 1/9ND & $1 / 1 \Delta \Lambda$ & $r q / \Delta r$ & ناتوانى در توصيف \\
\hline$\cdot / 4 \Delta$ & قوى & $1 / 290$ & $1 / v 90$ & IV/aF & سبك تفكر عينى \\
\hline
\end{tabular}

مى توان كفـت، آموزش به كار كرفته شــده موجب نارســايى

هيجـانى مراجعـان و خردهمقيـاس هاى ناتوانى در شــناســايى احساسات و سبك تفكر عينى شده است.
همان طور كه در جدول r مشاهده مى شود، ميزان به دست آمـده از ضــريسب d كوهن و ضــريب g هد معنادارى هو/· معنى دار اسـت، از اين رو با توجه به ميانكين به دست آمده از بيش آزمون و يس آزمون متغير نارسايى هيجانى 


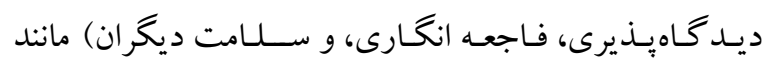

ميانگين، انحر اف معيار، كجى، كشيدگىى، كمترين و بيشترين،

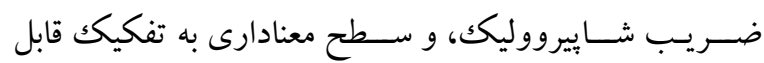

$$
\text { مشاهده است. }
$$

در جدول \& شاخص هاى آمار توصيفى نمر ات ييش آزمون،

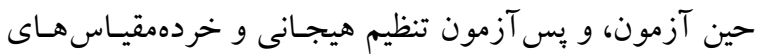

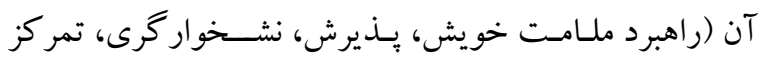

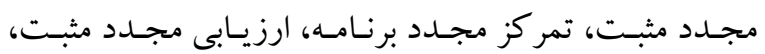

جدول ع: شاخصهاى توصيفى نمرات تنطيم هيجانى و خردهمقياسهاى آن قبل از شروع درمان، حين درمان، و در پايان درمان

\begin{tabular}{|c|c|c|c|c|c|c|c|c|c|}
\hline $\mathbf{p}$ & شإيرووليك & بيشترين & كمترين & كشيدكى & كجى & انحراف & ميانكين & وضعيت & متغير \\
\hline .190 & $\cdot|A|$ & f. & ro & .190 & .190 & $\Delta / \Upsilon \Lambda$ & $r V / 9 \Delta$ & يَيش آزمون & \multirow{3}{*}{ خواشبرد ملامت } \\
\hline$\cdot / r 1$ & $\cdot / \wedge \Delta$ & ro & rl & $\cdot / 0$ & • & $\Delta / 91$ & Tr/Tr & حين آزمون & \\
\hline • & $\cdot / \wedge 9$ & $\mu F$ & rI & .190 & $\cdot / 19$ & $\varphi / f$. & $19 / 71$ & پِ آزمون & \\
\hline$\cdot / 4 r$ & $\cdot / 9$ & $r$. & ir & $1 / r \Delta$ & . & $q / r q$ & $19 / \pi \Delta$ & بيش آزمون & \multirow{4}{*}{ يذيرش } \\
\hline .119 & $\cdot / / 9$ & rv & ro & $\cdot / / q$ & • & $\Delta / Q F$ & ه & حين آزمون & \\
\hline$\cdot / \Delta F$ & $\cdot / A \cdot$ & fr & $r$. & $\cdot / v \Delta$ &.$/ 94$ & $9 / 49$ & $r q / 99$ & ֵِ آزمون & \\
\hline$\cdot / r \Delta$ & $\cdot / \wedge 9$ & rq & Y & .191 & $\cdot / \mu r$ & $\Delta / 9 \vee$ & $r \Delta / 90$ & يِيش آزمون & \\
\hline$\cdot 109$ & $\cdot / \mathrm{AV}$ & r & 11 & $1 / r V$ & . & $\Delta / F F$ & $r q / 9 r$ & حين آزمون & \multirow{2}{*}{ نشخوارگرى } \\
\hline$\cdot / A r$ & $\cdot / 19$ & rr & if & .194 & $\cdot / 49$ & $\varphi / \Delta \Delta$ & $r \cdot / N F$ & يس آزمون & \\
\hline$\cdot 190$ & $\cdot / 19$ & $r$. & 10 & I/YF & . & $F / r$. & $\mid V / 9 \Lambda$ & بِيش آزمون & \\
\hline$\cdot / \mu F$ & $\cdot / \mathrm{AV}$ & $r$. & rr & ه ه & $\cdot / 41$ & $\Delta / r \Delta$ & YV/9D & حين آزمون & تمركز مجدد \\
\hline$\cdot|4|$ & $\cdot / 9$ & r & ro & $\cdot / \mathrm{VA}$ & . & $\Delta / \Delta$. & $r \cdot / 4 q$ & يس آزمون & مثبت \\
\hline$\cdot / A r$ & . $/ 9 r$ & 19 & 11 &.$/ 91$ & $\cdot / \Delta 1$ & $r / 99$ & $1 \% / 90$ & يّش آزمون & \multirow{3}{*}{ تمركز مجدد بر } \\
\hline •/ar & . & rq & rr & .194 & $\cdot / r \wedge$ & $\Delta / \cdot \Delta$ & $r \Delta / \Delta Q$ & حين آزمون & \\
\hline$\cdot / \mu 1$ & $\cdot / M \Lambda$ & rq & $r F$ & .191 & $\cdot / \wedge 9$ & $9 / 19$ & rN/rq & يس آزمون & \\
\hline$\cdot / 01$ & $\cdot / 19$ & YF & 11 & $\cdot / A F$ & $\cdot / 49$ & $F / \Delta F$ & $r \cdot 190$ & يبش آزمون & \multirow{4}{*}{ مثبت مجيت مجدد } \\
\hline • & $\cdot / 9$ & $r$. & $r$. & $\cdot / \mu F$ & $\cdot / r \Delta$ & $\Delta / I V$ & rG/VF & حين آزمون & \\
\hline$\cdot / r$ & $\cdot / 9 r$ & rr & rA & .194 & $\cdot / V 9$ & $\Delta / 9 Y$ & $M 1 / 9 \Lambda$ & يس آزمون & \\
\hline$\cdot / r \wedge$ & $\cdot / 19$ & ro & 11 & $\cdot / r \wedge$ & ه & $4 / 90$ & $r \mid / 9 \Lambda$ & يِش آزمون & \\
\hline$\cdot / r F$ & $\cdot / 19$ & ro & rq & $\cdot / \wedge \vee$ & $\cdot / A F$ & $\Delta / V G$ & rr/Tr & حين آزمون & \multirow{2}{*}{ ديد كاهذيرى } \\
\hline$\cdot 194$ & $\cdot / 19$ & rv & TV & $\cdot / 09$ & $\cdot 190$ & $\Delta / A V$ & $M Y / D G$ & پِ آزمون & \\
\hline$\cdot / r V$ & $\cdot / \mathrm{AV}$ & kr & $r F$ & . & $\cdot / 9 V$ & $9 / 4 \Delta$ & $41 / 90$ & يِيش آزمون & \multirow{4}{*}{ فاجعهانگارى } \\
\hline$\cdot 194$ & $\cdot / \mathrm{Va}$ & rv & $r$. & $\cdot / 19$ & Drs & $\Delta / M$ & $M F / 9 D$ & حين آزمون & \\
\hline$\cdot / \mu F$ & $\cdot / 9 F$ & rr & rr & .190 & $\cdot / \Delta 1$ & $\Delta / 9 Y$ & rI/90 & يس آزمون & \\
\hline . & $\cdot / \wedge 9$ & rI & 10 & $1 / 49$ & $\cdot / r \Delta$ & $F / Y \Lambda$ & MN/Tr & بيش آزمون & \\
\hline$\cdot / r F$ & - /AF & ro & 19 & $1 / 99$ & $\cdot / r V$ & $f / 94$ & $r \mid / \Delta q$ & حين آزمون & \multirow{2}{*}{ سلامت ديخر ان } \\
\hline $.19 \mathrm{~V}$ & $\cdot / \Lambda \mu$ & rV & rF & $\cdot / 91$ & $\cdot / 94$ & $p / q$. & $r F / \cdot V$ & پِ آزمون & \\
\hline
\end{tabular}

هيجانى و خردهمقياس هاى آن جهت سنجش تفاوت قبل و بعد

از آموزش كزارش شده است.
در جدول ه نتايج به دســت آمده از اندازه از اندازه اثر d

كوهن و g هـد 
جدول 0: مقايسه نمر ات تنظيم هيجانى و خردهمقياسهاى آن جهت سنجش تفاوت قبل و بعد از آموزش تنظيم هيجانى

\begin{tabular}{|c|c|c|c|c|c|}
\hline درصد تغييرات & تفسير اندازه اثر & ضريب dكوهن & ضريب g هدكس & تفاوت ميانغين & \\
\hline$\cdot / \mu$ & قوى & $1 / r \cdot \Delta$ & $1 / 4 Y T$ & $r Y / 90$ & راهبرد ملامت خويش \\
\hline$\cdot / 1 \wedge$ & قوى & $1 / \pi / f$ & $1 / T F \mid$ & $\Gamma / 90$ & يذ يذ يرش \\
\hline .191 & قوى & $1 / 949$ & I/TrS & ra/ro & نشخوارگرى \\
\hline 然 & قوى & $1 / v 90$ & $|/ \Gamma \wedge|$ & $r V / 90$ & تمركز مجدد مثبت \\
\hline$\cdot / \pi \Delta$ & قوى & $1 / \mu r$ & $1 / . \Delta 9$ & rN/9N & تمركز مجدد بر برنامه \\
\hline$\cdot / 4 q$ & قوى & $1 / 09 \Delta$ & $1 / \pi+1$ & rY/90 & ارزيابى مجدد مثبت \\
\hline$\cdot 109$ & قوى & $1 / . \Delta 9$ & $1 / 919$ & 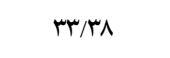 & ديد گاهيذيرى \\
\hline$\cdot / V^{F}$ & قوى & $1 / 9 \wedge \Delta$ & $1 / N+1$ & HE/VG & فاجعهانگًارى \\
\hline$\cdot / \mu$ & قوى & $1 / r \Delta r$ & $1 / 90 \mathrm{~V}$ & $M F / 9 Y$ & سلامت ديخران \\
\hline
\end{tabular}

در جدول 9 شاخصهاى آمار توصيفى نمرات بيش آزمون،

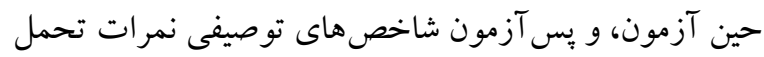

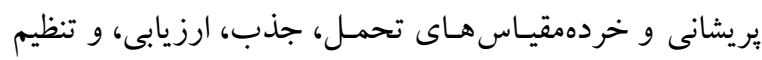
قبـل از شــروع درمـان، حين درمـان، و در پِايـان درمان مانند

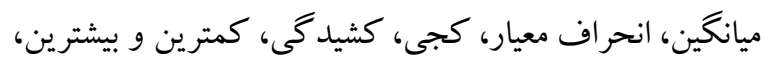

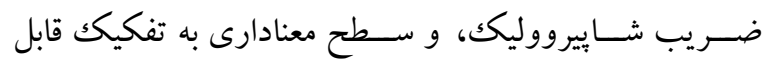

همان طور كه در جدول ها مشاهده مى شود، ميزان به دست

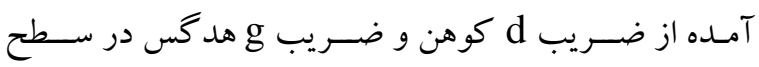

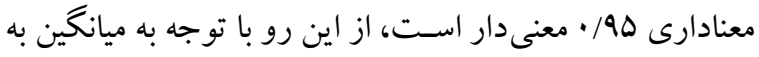

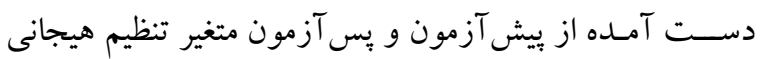
مى توان كفت، آموزش مورد نظر موجب بهبود تنظيم هيجانات

$$
\text { مشاهده است. }
$$

جدول 7: شاخصهاى توصيفى نمرات تحمل يريشانى و خردهمقياسهاى تحمل، جذب، ارزيابى، و تنظيم قبل از شروع درمان، حين درمان، و در پايان

\begin{tabular}{|c|c|c|c|c|c|c|c|c|c|}
\hline $\mathbf{p}$ & ضريب & بيشترين & كمترين & كشيدى & كجى & انحر اف & ميانگين & وضعيت & متغير \\
\hline$\cdot / \cdot Y I$ & .190 & rq & 11 & .190 & .190 & $F / 99$ & $T F / 9 D$ & ييش آزمون & \\
\hline .190 & $\cdot 19 V$ & rA & YI & $\cdot / F \Delta$ & $\cdot / Y F$ & $\Delta / .9$ & $r \Delta / 9 \Delta$ & حين آزمون & تحمل \\
\hline$\cdot / \mathrm{V} \wedge$ & $\cdot 191$ & ro & rA & $1 / 90$ &.$/ 49$ & $\Delta / 9$. & $M \mid / F \Delta$ & يس آزمون & \\
\hline .194 & .190 & $r q$ & $r$. & $\cdot / r V$ & $\cdot / 199$ & $F / 9 r$ & טF/T & ييش آزمون & \\
\hline .190 & $\cdot 1199$ & Mr & ro & - /A9 & $\cdot / V \Delta$ & $\Delta / \Delta q$ & هץ/ & حين آزمون & جذب \\
\hline$\cdot / \mathrm{V} \wedge$ & $\cdot / 91$ & rA & r. & $\cdot / r V$ & $\cdot / 9 \Delta$ & $9 / . r$ & rG/MF & يس آزمون & \\
\hline .194 & $\cdot / \mathrm{AV}$ & rV & 11 & $\cdot / \mathrm{AV}$ & $\cdot / Y \Delta$ & $F / V Y$ & هr/r & يِش آزمون & \\
\hline$\cdot / \cdot \Delta$ & $\cdot / \mathrm{V} 9$ & $r q$ & rI & $\cdot / \Delta V$ & $\cdot / V \Delta$ & س & $r \Lambda / F \Delta$ & حين آزمون & ارزيابى \\
\hline .191 & $\cdot / \Lambda$ & Mr & IV & $\cdot 191$ & $\cdot /$ / & $F / 9 Y$ & טז/TI & يس آزمون & \\
\hline . TFF & .190 & YF & 19 & $\cdot 19 \Lambda$ & $\cdot / \mathrm{V} \Lambda$ & $F / F q$ & $r \cdot / Y F$ & يِش آزمون & \\
\hline$\cdot / \mathrm{V} \Lambda$ & $\cdot / \wedge 9$ & TM & ro & $\cdot 19 \Lambda$ & .190 & س & $r V / F D$ & حين آزمون & تنظيم \\
\hline .191 & $\cdot|\Lambda|$ & pr & ו & $\cdot / r V$ & $\cdot / \mu V$ & $9 / r 1$ & rN/9N & يس آزمون & \\
\hline
\end{tabular}

$$
\begin{aligned}
& \text { در جدول Vنتايج به دست آمده از اندازه اثر d كوهن و g g و }
\end{aligned}
$$

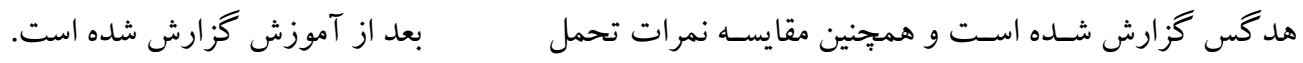




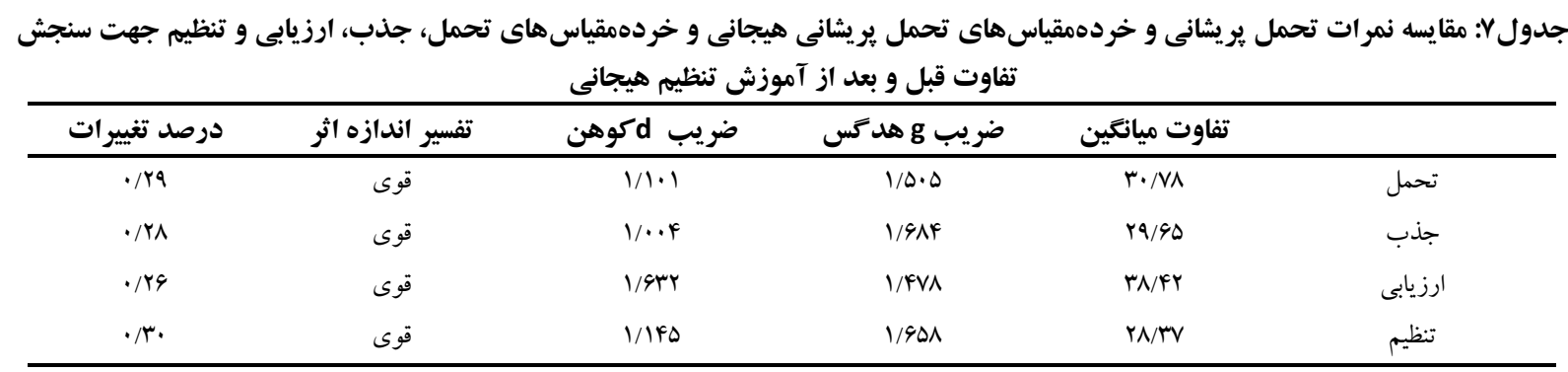

افراد حداقل يكك بار در زندگيشان عمل خودارضايى را انجام دادهاند. خودارضـيى از اين جهت، يكك تمايل جنسى نابهنجار

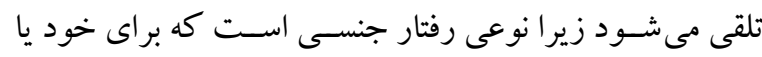

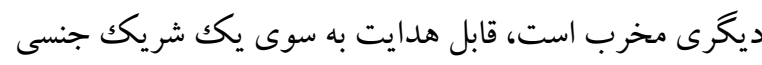
نيست، تحريكك اعضاء جنسى اوليه را مستنىى مىدارد، به طور

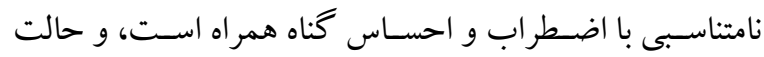
جبرى دارد (سT) و بـه همين دليـل در اين يُزوهش از آموزش تحمل بريشانى استفاده شد.

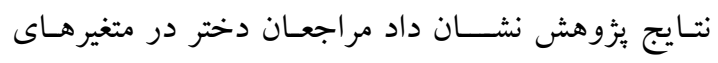
نارسـايى هيجانى و تنظيم هيجانى بهبودى بيشـترى نسـبت به

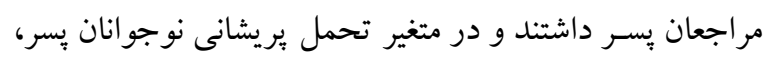
بهبودى بيشـترى داشـتند. بررسـىها نشـان مى دهند كه عمل خودارضايى در بين بسـران زودتر از دختران شروع مى شود و

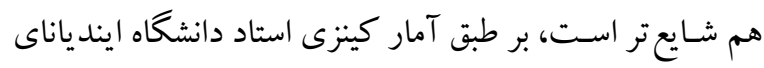

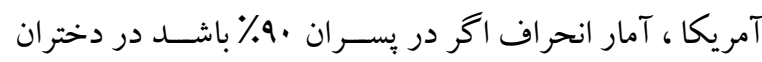

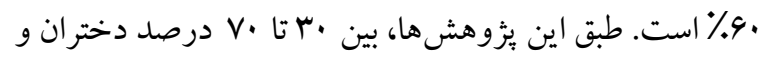

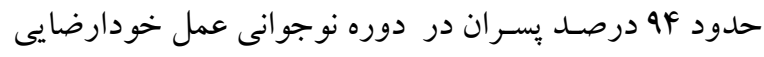

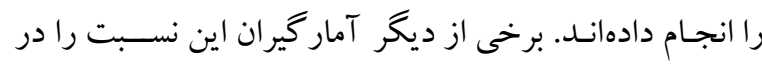

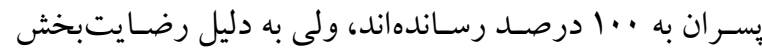
نبودن مطالعات روى دختران معتقدند كه اين جنس حاضــر

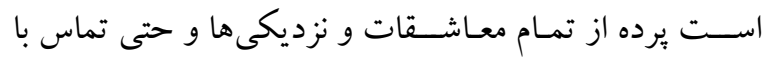

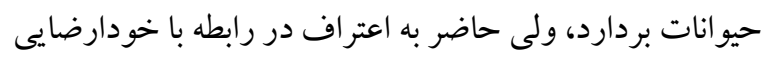

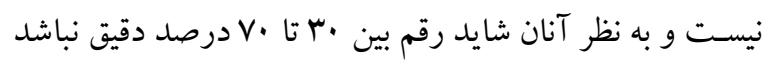

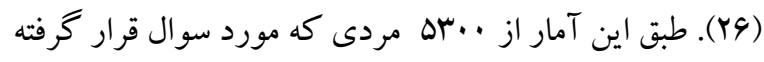

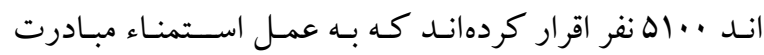

همان طور كه در جدول V مشاهده مى شود، ميزان به دست

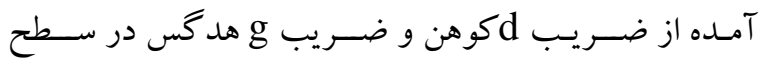

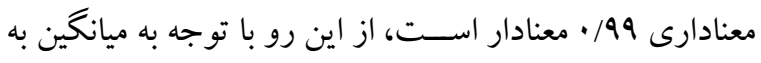
دست آمده از يِيش آزمون و بِ آزمون متغير تحمل بريشـانى

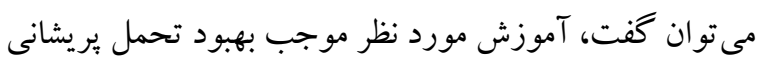
و خرده مقياس هاى آن شده است.

\section{بحث و نتيجه كيرى}

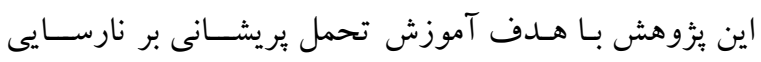

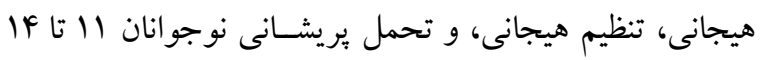

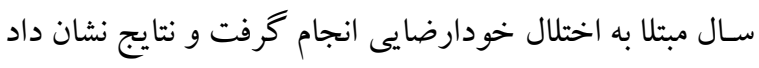
كه آموزش تحمل يريشـانى بر ناتوانى نارسـايى هيجانى، تنظيم

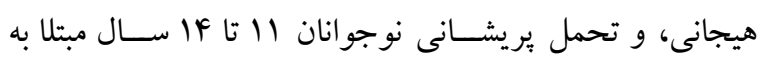

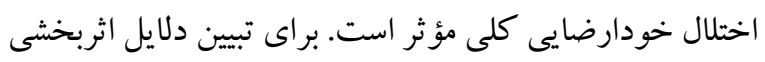

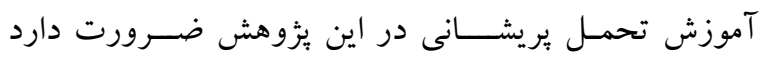

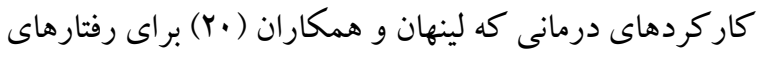

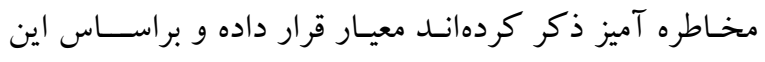
معيارها، فرايند درمانى آزمايش شده، به صورت كيفى ارزيابى درد شود: خودارضــايى زمانى يـك اختلال جنسـى و يكك علامت

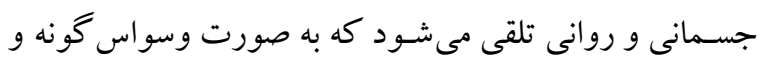
فراسوى مهار عمدى شخص در آيد. در جنين حالتى، علامتى از

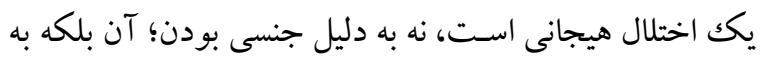

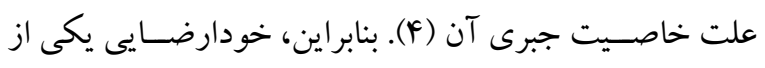

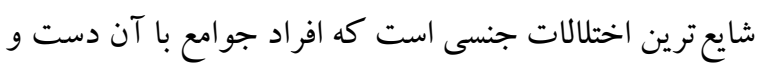

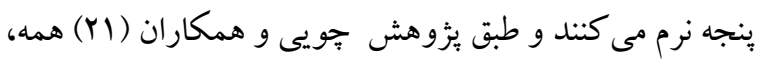


دردهاى هيجانى مىشـود، همسو است. البته للازم به ذكر است

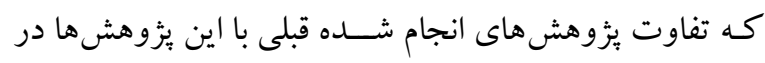

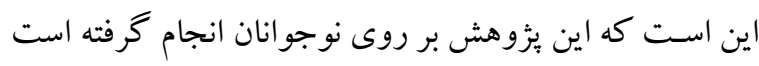

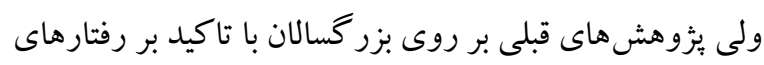
مقابلهاى انجام شـده است و دلايل اثربخشى در آن بثزوهشى برها، تمر كز بر كمـال كرايىهـاى منفى بوده اســت كـه از مهم ترين مهارت ها در آموزش هاى ياسخ مقابلهاى است. مهارت هاى جلسات ششم تا هشتم منجر به كاهش معنى ماردار

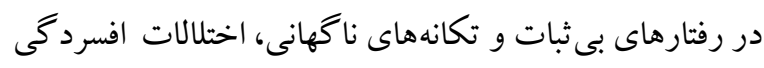

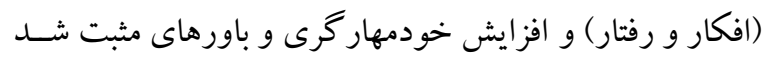

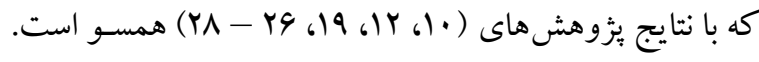
همه اين مطالعات مؤيد اثربخشسى آموزش تحمل يريشـانى در

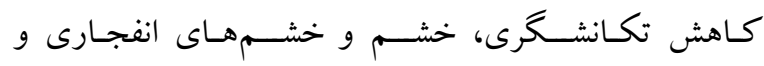
تحريككيذيرى در افراد مورد مطالعه هسـتند؛ با اين تفاوت حهن

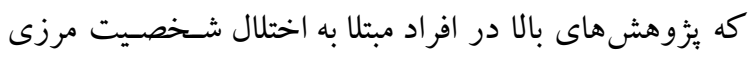

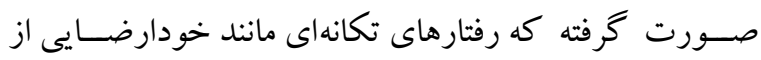

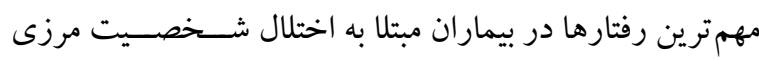

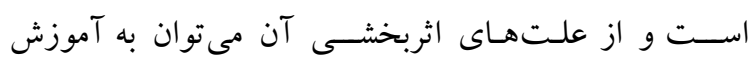

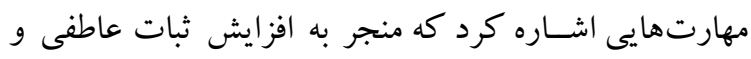

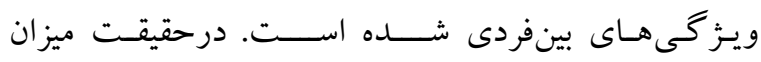

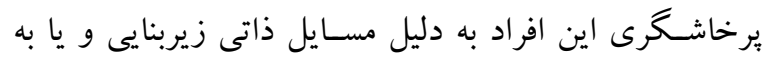

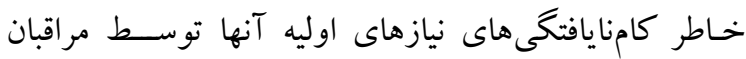

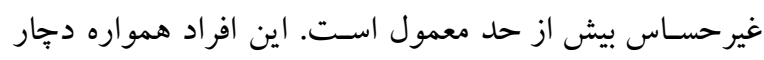

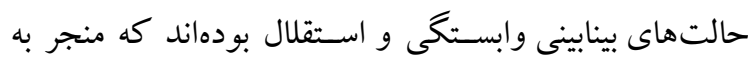

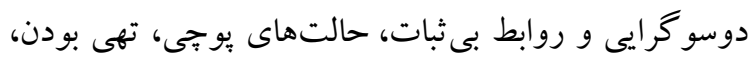

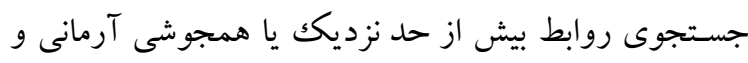

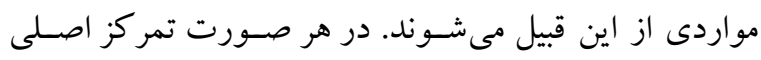

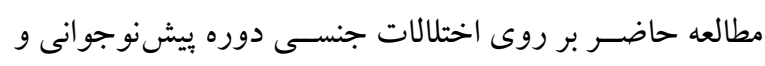

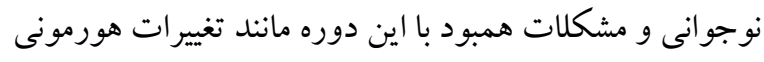

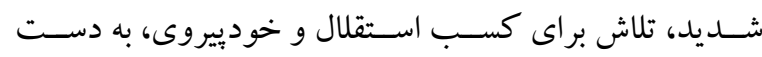
آوردن حرمت خود و حس انسجام هويت، انجام شد كه نتايج آن مطلوب و رضايتبخش بهدست آمده است.
ورزيدهاند (YV). مسلماٌ جنين آمارى تا حد زيادى احساس گناه افر اد مبتلا به خودارضايى را كاهش مىدهد (YN).

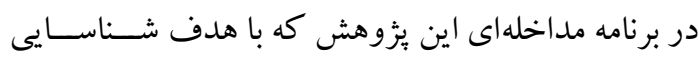

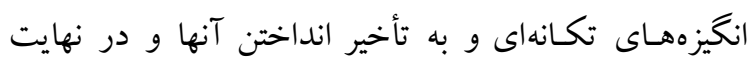
كاهش تمايلات شـديد و غير رادى براى عمل اسـت (11) صسورت گرفت، به آزمودنى ها قدرت حل مسـئله در شــــ ايط

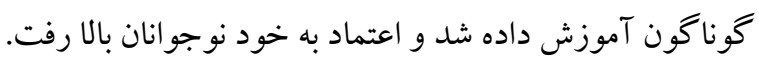
در اين درمان ارزيابى و شناخت افكار و احساسات كه منجر

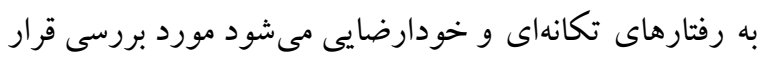

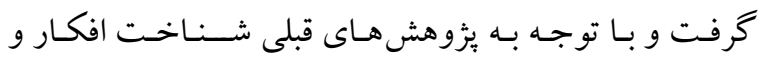

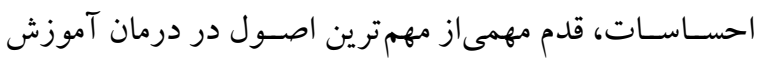
تحمل بريشـانى اسـت كه موجب كاهش رفتارهاى ناخهانى

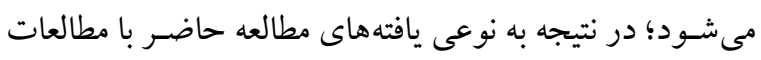

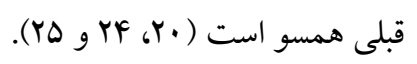

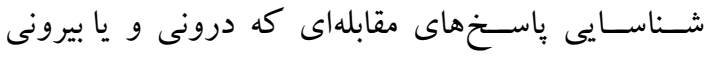
هستند كه منجر به راهبردهاى سازش نايافتهاى مى شوند (r. (r)

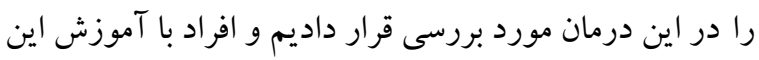

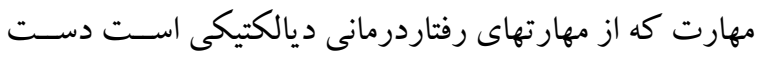

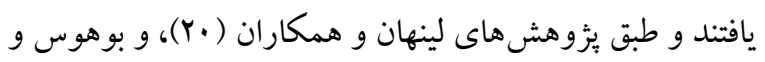

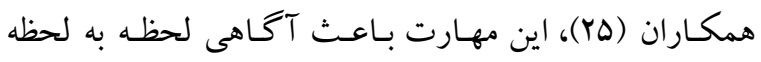

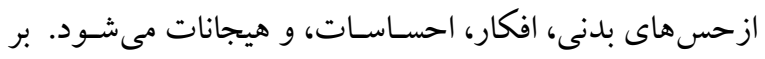
اساس نتايج مطالعات لينهان و همكاران (·r) مى توان اين كونه تبيين كرد كه آموزش تحمل بريشــانى منجر به شــناسـايى

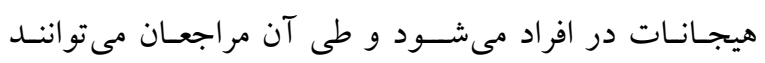

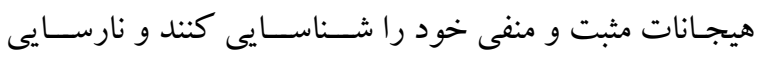
هيجانى، تنظيم هيجانى، و تحمل يريشانى را بهبود بخشند.

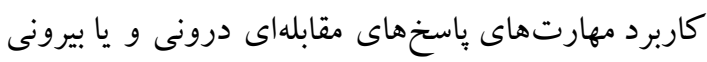

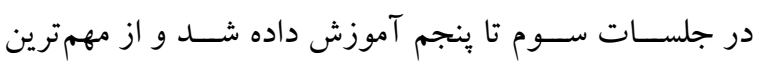
جلسـات درمان هيجانات سـازشنايافته به شمار مىرفت. نتايج حاصـل از اجراى اين مداخله با برزوهشهاى زمانى و همكاران (19 مبنى بر اين كه آموزش تحمل بريشـانى در درمان

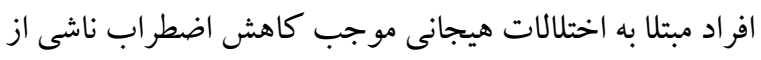


يروتكل استفاده شده در اين مطالعه در قالب دورههاى آموزش عمومى و تخصصى فوق برنامه در مدارس دختر انه و يسر انه در

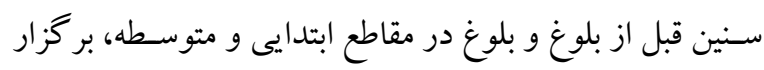

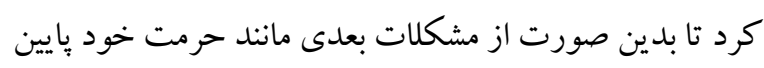

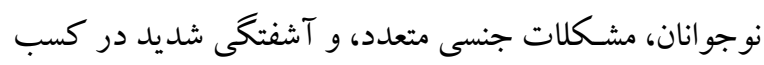

$$
\text { هويت جلو گيرى كرد. }
$$

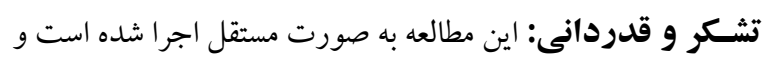

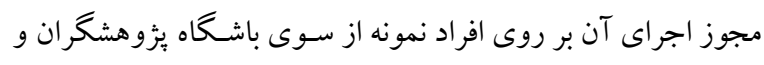

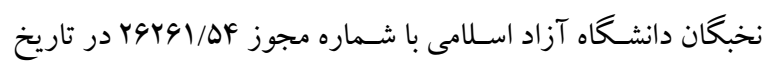

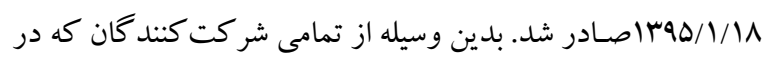

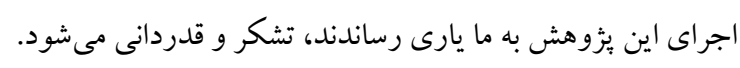
تضاد منافع: هيجگگ نه تعارض منافع توسط نويسند گان بيان نشده است.

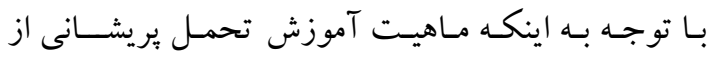

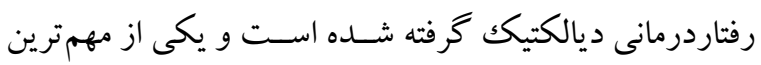
مهارتهاى مبتنى بر يذيرش اسـت بنابر اين نتايج مطالعه حاضر

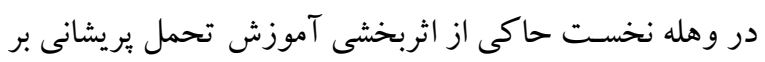

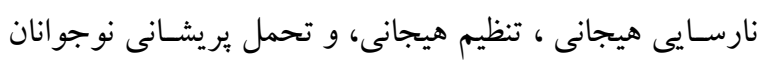

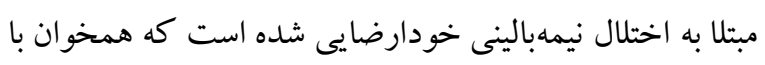
نتايج يثزوهش هاى مطرح شـده در بخش هاى قبلى است. در هر

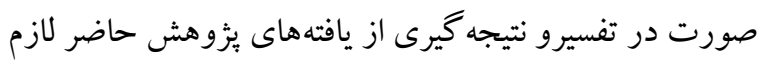

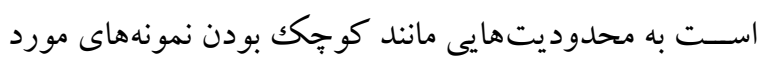
مطالعه، عدم ييخيرى طولانى مدت ارزيابىها، و نبود گروه گُ اه توجـه شــود. بر اين اســاس براى نتيجـهـ گيرى نهايى، تكرار

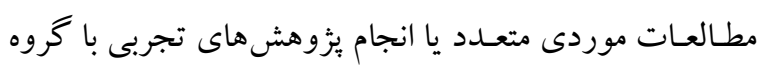

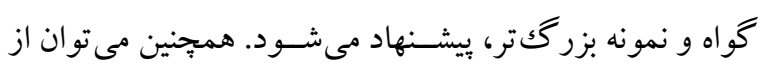




\section{References}

1. Freud S. Three essays on the theory of sexuality (1905). In: Strachey J, Freud A, Strachey A, Tyson A, editor. The standard edition of the complete psychological works of Sigmund Freud volume vii (19011905): a case of hysteria, three essays on sexuality and other works. 1953, pp: 123-246. [Link]

2. Sadock BJ, Sadock VA. Kaplan \& Sadock's synopsis of psychiatry: Behavioral sciences/clinical psychiatry. 10th ed. Philadelphia, PA, US: Lippincott Williams \& Wilkins; 2007, pp: 314-359. [Link]

3. Sue D, Sue DW, Sue S, Sue DM. Understanding abnormal behavior. 11th ed. United States: Cengage Learning; 2015, pp: 29-63. [Link]

4. Chivers ML, Seto MC, Blanchard R. Gender and sexual orientation differences in sexual response to sexual activities versus gender of actors in sexual films. J Pers Soc Psychol. 2007; 93(6): 1108-1121. [Link]

5. Bancroft J, Vukadinovic Z. Sexual addiction, sexual compulsivity, sexual impulsivity, or what? Toward a theaoretical model. J Sex Res. 2004; 41(3): 225-234. [Link]

6. Laumann EO, Mahay J. The social organization of women's sexuality. In: Wingood GM, DiClemente RJ, editors. Handbook of women's sexual and reproductive health. Boston, MA: Springer US; 2002, pp: 43-70. [Link]

7. Browning CR, Laumann EO. Sexual contact between children and adults: A life course perspective. Am Sociol Rev. 1997; 62(4): 540-560. [Link]

8. Das A, Parish WL, Laumann EO. Masturbation in Urban China. Arch Sex Behav. 2009; 38(1): 108120. [Link]

9. Bancroft J. Human sexuality and its problems. Elsevier Health Sciences; 2008, pp: 403-529. [Link]

10. Das A. Masturbation in the United States. J Sex Marital Ther. 2007; 33(4): 301-317. [Link]

11. Kaplan HS. New sex therapy: active treatment of sexual dysfunctions. New York, NY: Routledge; 2013, pp: 140-143. [Link]

12. Kusow AM. African immigrants in the United States: Implications for affirmative action. Sociology Mind. 2014; 4(1): 74-83. [Link]

13. Kim J, Kemegue F. Addressing the low returns to education of African born immigrants in the United States. Economics Working Papers [Internet]. 2007 May 15; Available from: [Link]

14. McQuillan A, Nicastro R, Guenot F, Girard M, Lissner C, Ferrero F. Intensive dialectical behavior therapy for outpatients with borderline personality disorder who are in crisis. Psychiatr Serv. 2005; 56(2): 193-197. [Link]

15. Zahediyan S, Kafi Masule SM, Khosrov Javid M, Fallahi M. Efficacy of emotion regulation training on coping strategies among female elementary school students. Journal of Child Mental Health. 2015; 2(1): 9-19. [Persian]. [Link]

16. Zamani N, Zamani S, Habibi M, Abedini S. Comparison in stress of caring mothers of children with developmental, external and internal disorders and normal children. Journal of Research and Health. 2017; 7(2): 688-694. [Link]

17. Zamani N, Abyar Z, Jenaabadi H, Zamani S. Effect of impulse control training on depression and anxiety mother of children with developmental coordination disorders. Journal of Research and Health. 2017; 7(5): 1012-1020. [Link]

18. Mahmoud Alilou M, Khanjani Z, Bayat A. Comparing the coping strategies and emotion regulation of students with symptoms of anxiety-related emotional disorders and normal group. Journal of Child Mental Health. 2016; 3(1): 41-51. [Persian]. [Link]

19. Massey DS, Mooney M, Torres KC, Charles CZ. Black Immigrants and black natives attending selective colleges and universities in the United States. Am J Educ. 2007; 113(2): 243-271. [Link]

20. Linehan MM, Dimeff LA, Reynolds SK, Comtois KA, Welch SS, Heagerty P, et al. Dialectical behavior therapy versus comprehensive validation therapy plus 12-step for the treatment of opioid dependent women meeting criteria for borderline personality disorder. Drug Alcohol Depend. 2002; 67(1): 13-26. [Link] 
21. Choi YJ, Lee WH, Rha KH, Xin ZC, Choi YD, Choi HK. Masturbation and its relationship to sexual activities of young males in Korean military service. Yonsei Med J. 2000; 41(2): 205-208. [Link]

22. Chamzadeh Ghanavati M, Aghaei A, Golparvar M. The effect of positive â thinking skills on the pessimistic documentary style in primary school boys. Research in Curriculum Planning. 2016; 12(47): 43-50. [Persian]. [Link]

23. Oliver MB, Hyde JS. Gender differences in sexuality: a meta-analysis. Psychol Bull. 1993; 114(1): 29 51. [Link]

24. Fernández-Castro J, Rovira T, Doval E, Edo S. Optimism and perceived competence: The same or different constructs? Pers Individ Dif. 2009; 46(7): 735-740. [Link]

25. Bohus M, Haaf B, Simms T, Limberger MF, Schmahl C, Unckel C, et al. Effectiveness of inpatient dialectical behavioral therapy for borderline personality disorder: a controlled trial. Behav Res Ther. 2004; 42(5): 487-499. [Link]

26. Goldstein S, Goldstein M. Managing attention deficit hyperactivity disorder in children: A guide for practitioners, 2nd ed. Hoboken, NJ, US: John Wiley \& Sons Inc; 1998. [Link]

27. Poushaneh K, Bonab BG, Namin FH. Effect of training impulse control on increase attention of children with attention - deficit/ hyperactivity disorder. Procedia Soc Behav Sci. 2010; 5: 983-987. [Link]

28. Nijmeijer JS, Minderaa RB, Buitelaar JK, Mulligan A, Hartman CA, Hoekstra PJ. Attentiondeficit/hyperactivity disorder and social dysfunctioning. Clin Psychol Rev. 2008; 28(4): 692-708. [Link]

29. Delalatgar Langroude K, Hosseinkhanzadeh AA, Taher M, Mojarrad A. The Role of Emotionality and Self-control Ability in Explaining Risk Behaviors in Students. Journal of Child Mental Health. 2018; 5(1): 25-35. [Persian]. [Link]

30. Abolghasemi A, Rezaee Jamalui H, Herfati R. The relationship between alexithymia, child abuse and academic achievement among male high school students. The Journal of New Thoughts on Education. 2011; 7(3): 135-155. [Persian]. [Link]

31. Garnefski N, Kommer TVD, Kraaij V, Teerds J, Legerstee J, Onstein E. The relationship between cognitive emotion regulation strategies and emotional problems: comparison between a clinical and a non-clinical sample. Eur J Pers. 2002; 16(5): 403-420. [Link]

32. Samani S, Sadeghi L. Psychometric properties of the cognitive emotion regulation questionnaire. Journal of Psychological Models and Methods. 2010; 1(1): 51-62. [Persian]. [Link]

33. Fathi-Ashtiani A, Dastani M. Psychological tests: personality and mental health. Tehran: Besat; 2009. [Persian].

34. Alavi K, Modarres Gharavi M, Amin Yazdi SA, Salehi Fadardi J. Effectiveness of group dialectical behavior therapy (based on core mindfulness, distress tolerance and emotion regulation components) on depressive symptoms in university students. Journal of Fundamentals of Mental Health. 2011; 13(50): 124-135. [Persian]. [Link] 